\title{
Psychometric Characteristics of Multidimensional Measure of Nurses' Personal Resilience
}

\author{
Reza Soltani Shal ${ }^{1 *}$, Zahra Ahmadpour Turki², Maede Abbastabar Bozrudi ${ }^{3}$
}

1. Assistant Professor of Psychology, Department of Psychology, Faculty of Literature and Humanities, University of Guilan, Rasht, Iran

2. MA, Department of Psychology, Faculty of Literature and Humanities, University of Guilan, Rasht, Iran

3. MA Department of Psychology, Faculty of Psychology \& Educational Science, University of Kharazmi, Alborz, Karaj

\begin{tabular}{ll}
\hline Article Info & ABSTRACT \\
\cline { 3 - 4 }
\end{tabular}

Received: 2020/04/05;

Accepted: 2020/08/27;

Published Online: 2020/11/23

10.30699/sjhnmf.29.1.1

Original Article

Use your device to scan and read the article online

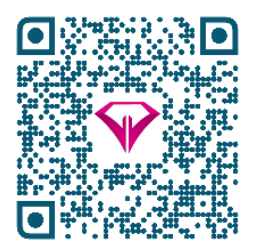

Corresponding Information:
Introduction: Nurses face too much stressors as work-rest cycle problems, overload responsibility, lack of vacation time and painful experiences of patients; therefore, resiliency can help them to appropriate and efficient cope with these stressors. But there is no brief and practical scale to assess psychological resiliency among nurses in Iran. So, the aim of the present study was to evaluate the psychometric properties of the multidimensional measure of nurses' personal resilience.

Methods: In this methodological study, 120 nurses from Amol's hospitals were studied using a convenience sampling method who filled the multidimensional measure of nurses' personal resilience. The multidimensional measure of nurses' personal resilience is composed of 40 items. The psychometric properties were examined through the Nominal validity, Content Validity, Concurrent validity, Construct validity. The data was analyzed by SPSS 22 .

Results: Nomianl and content validity were approved by five psychologists. The KMO index and Bartlett's test of sphericity indicated that correlation matrices were suitable for factor analysis. Factor analysis with Principal Component Analysis extracted one factor with $55.21 \%$ total variance. Internal consistency was confirmed by a Cronbach's alpha of 0.86 and there was no change in number of components or dimensions and questions.

Conclusion: This study showed that the multidimensional measure of nurses' personal resilience had appropriate psychometric properties and is a valid and reliable screening index to measure psychological resiliency of nurses. This index could facilitate the assessing of Well-Being in brief and practical way among nurses.

Keywords: The multidimensional measure of nurses' personal resilience, Validity, Reliability

Reza Soltani Shal, Assistant Professor of Psychology, Department of Psychology, Faculty of Literature and Humanities, University of Guilan, Rasht, Iran Email: soltani.psy@gmail.com

Copyright $\odot$ 2021, This is an original open-access article distributed under the terms of the Creative Commons Attribution-noncommercial 4.0 International License which permits copy and redistribution of the material just in noncommercial usages with proper citation.

How to Cite This Article:

Soltani Shal R, Ahmadpour Z, Abbastabar Bozrudi M. Psychometric Characteristics of Multidimensional Measure of Nurses’ Personal Resilience. Avicenna J Nurs Midwifery Care. 2020; 29 (1) :1-13 


\title{
ويزَّى هاى روانسنجى مقياس جندبعدى تاب آورى شخصى يرستاران
}

\section{رضا سلطانىشال "'، زهرا احمديور تركى؟، مائده عباستبار بزرودى"}

\author{
ا. استاديار، كروه روانشناسى، دانشكدة ادبيات و علوم انسانى، دانشكاه كيلان، رشت، ايران

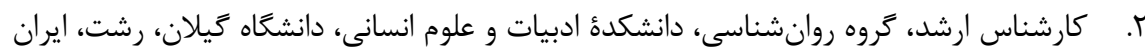

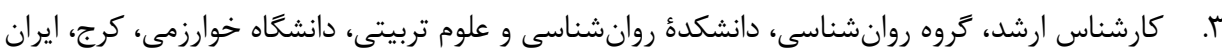

\begin{tabular}{|c|c|}
\hline جكيده & اطلاعات مقاله \\
\hline 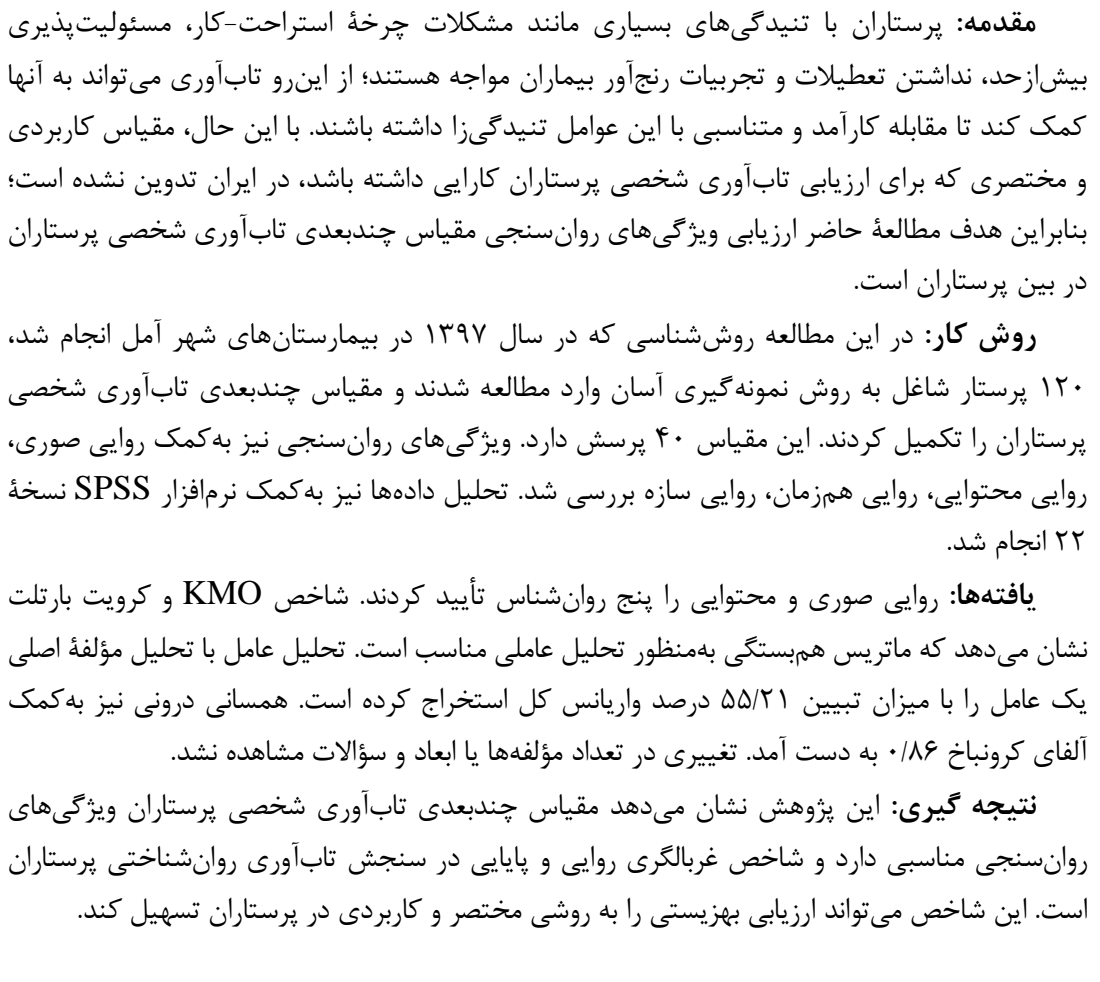 & 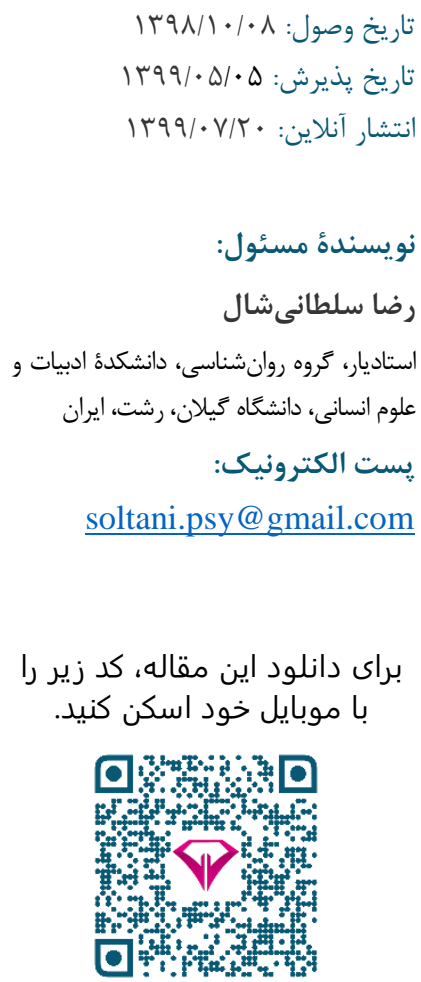 \\
\hline كليدوازهها: مقياس קندبعدى تابآورى شخصى يرستاران، روايى، پايايى & \\
\hline
\end{tabular}

يرستاران انكولوزى به اين نتيجه رسيد كه كيفيت زندگى اين

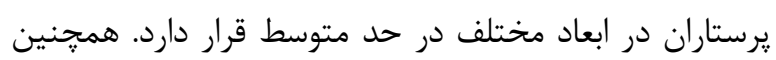

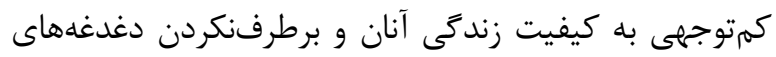

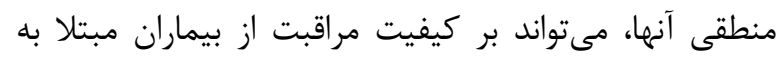

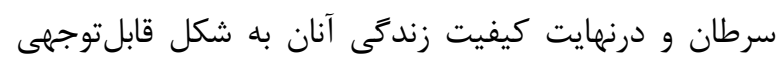

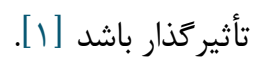
براساس مطالعات انجامشده بىتوجهى به كيفيت زندگى و باند بهداشت روانى برستاران مى تواند به ناميدى، از بين رفتن انخيزه كارى و انواع اختلالات روانشناختى و جسمانى منجر شود.
ماهيت برخى مشاغل با تنيدگى، تهديد، آسيب و اضطراب درهمييجيده است؛ بهزونهاى كه ممكن است سلامت روانى و

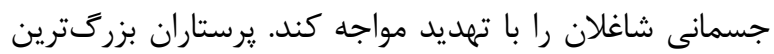
گروه ارائهدهنده خدمات بهداشتى-درمانى در همة كشورها

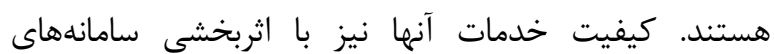

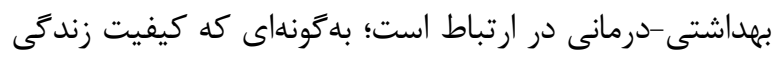

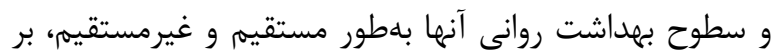
كيفيت و ايمنى خدمات يزشكى و درنهايت سلامتى بيماران

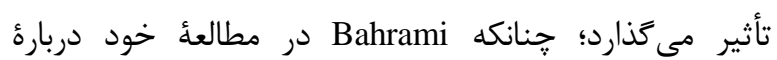


منجر شد [V]. درحقيقت، توجه به ظرفيتهاى فردى و روانى

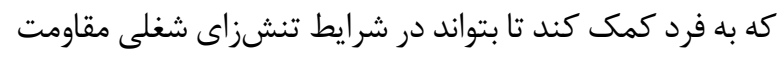

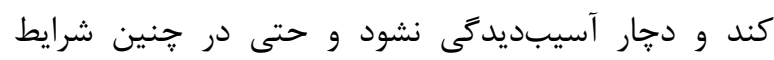

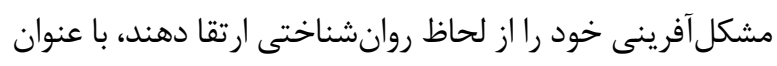

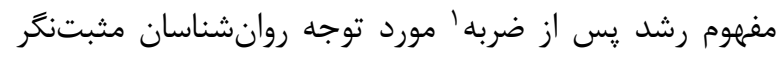

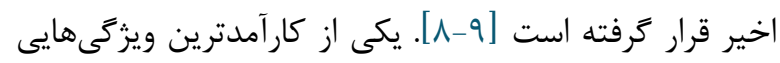

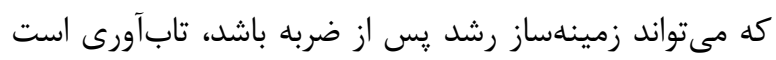

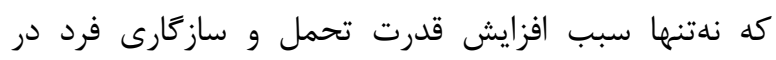

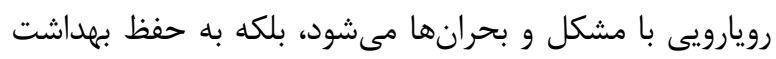

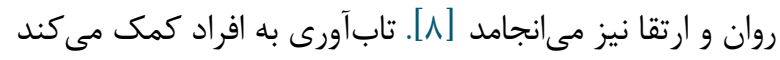

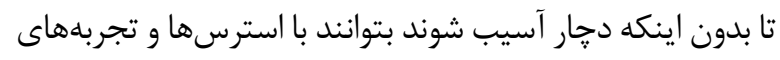
ناخوشايند و فشارزاى زندكى و شغلى مواجه شوند و و حتى ائى اين

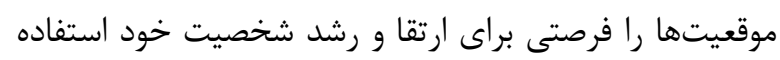

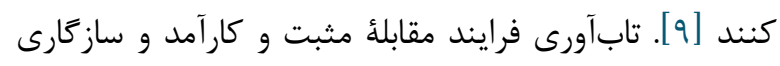

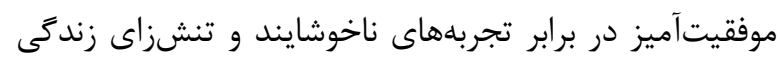

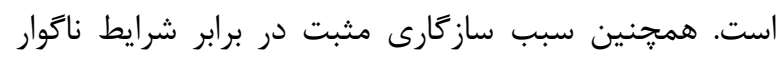

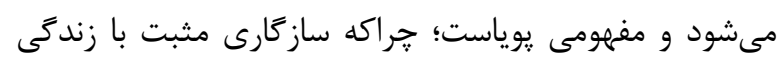

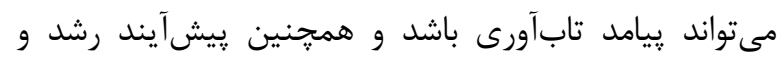

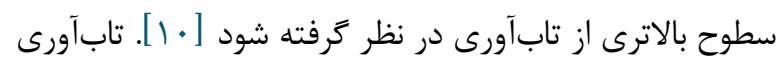

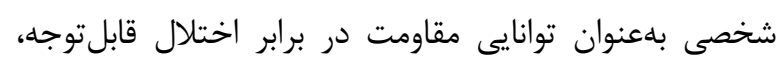

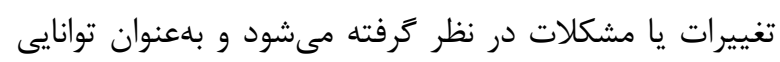

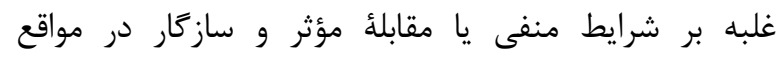
مواجهشدن با كمبود و سختى و مشكل توصيف مى شود و و تنها

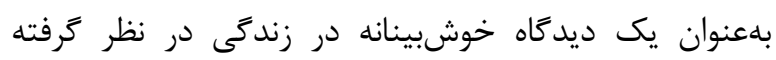

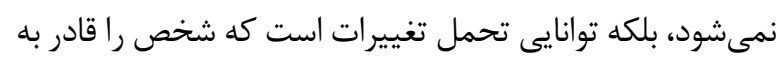

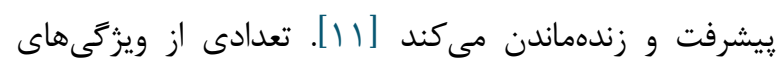

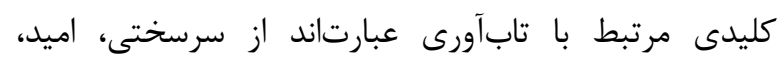

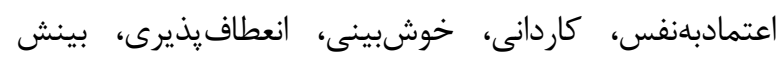

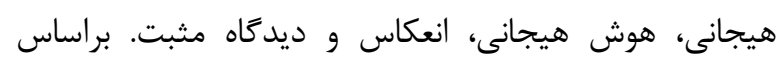

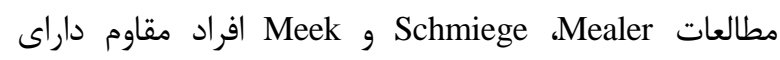

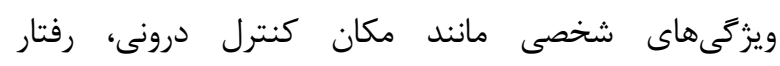

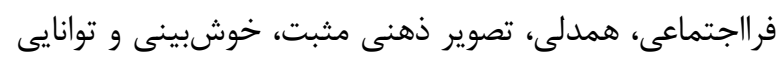

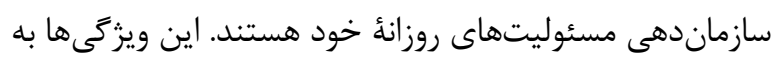

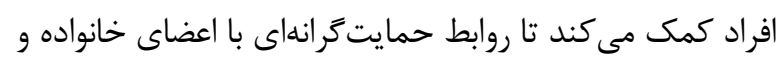

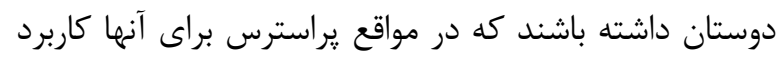

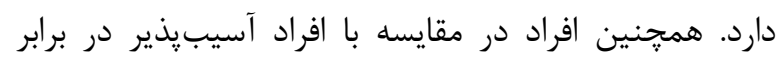

درحقيقت، دانستن اينكه يرستاران تا جه حد احس احساس

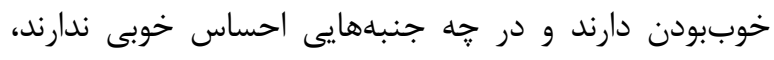

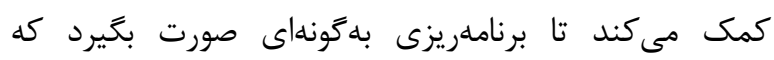

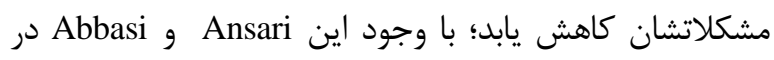

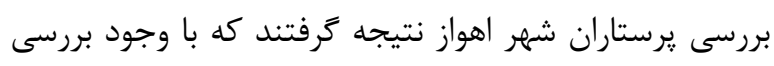

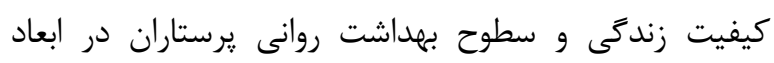

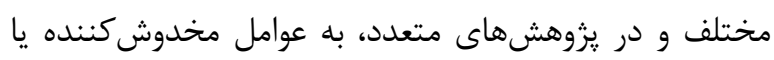

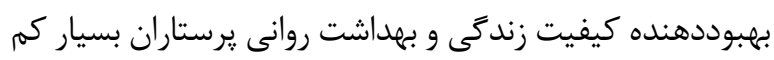

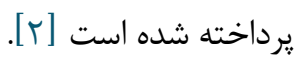

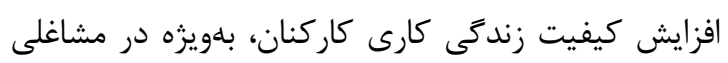

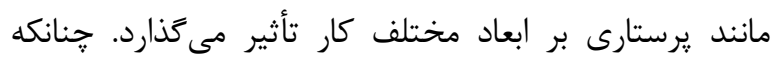

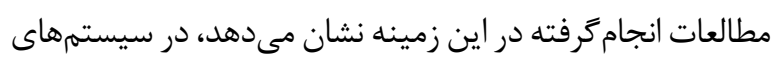

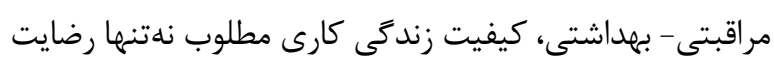

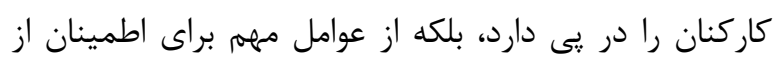

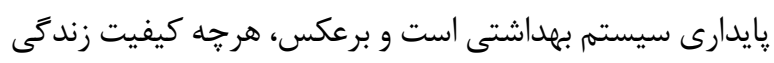

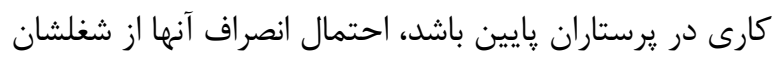

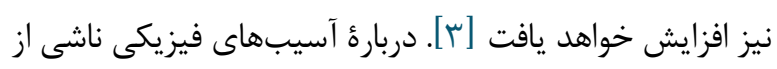

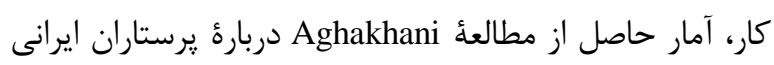

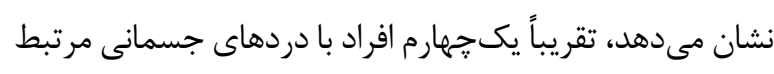

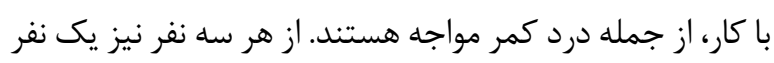

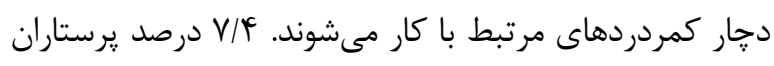

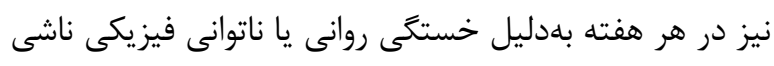

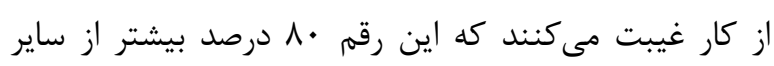

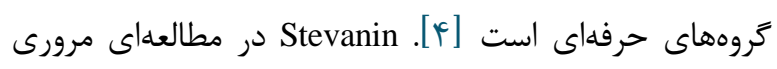

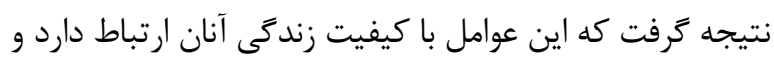

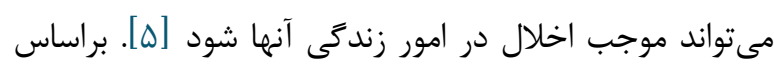

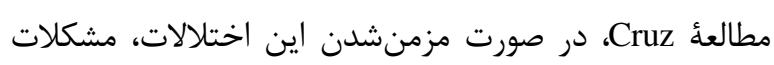

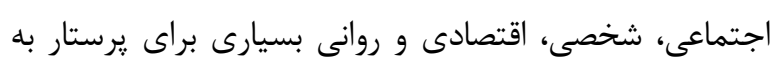

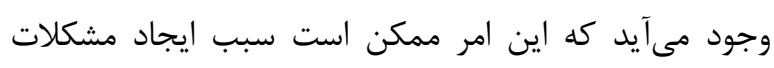

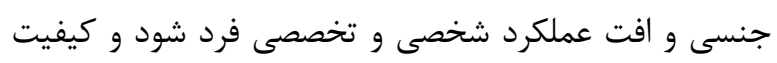

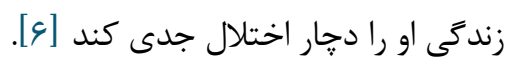

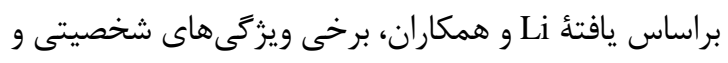

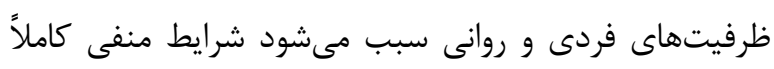

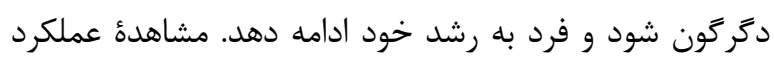

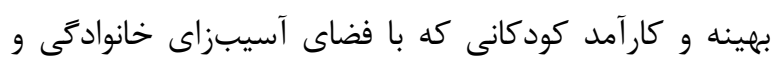

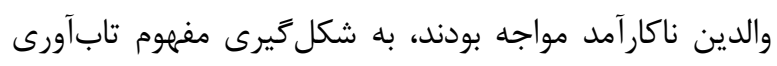

\section{Post Traumatic Growth}

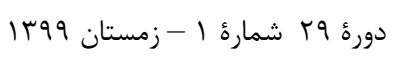


در محل كار با عوامل استرسزايى مانند كار بيشازحد، ازدياد

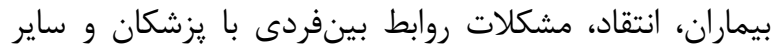

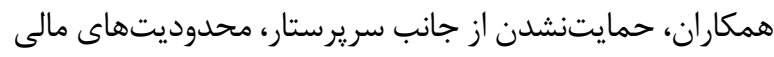

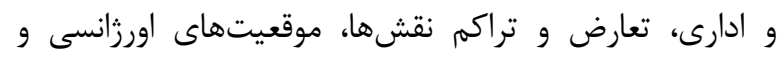

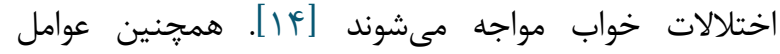
استرسزاى ديخرى براى برستاران معرفى شده است كه شئل شامل

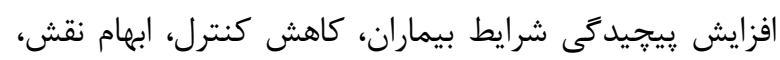

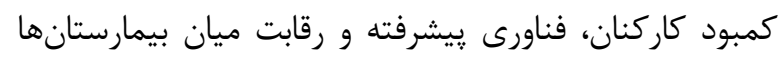

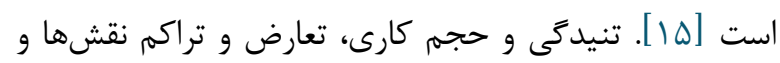

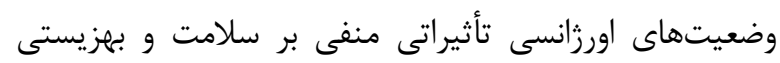

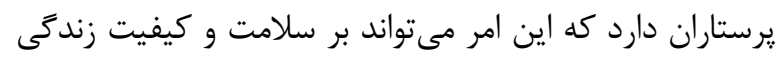

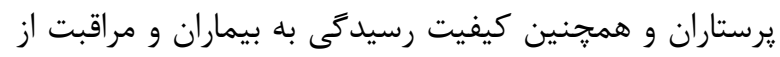

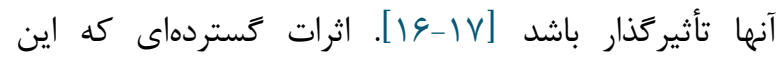

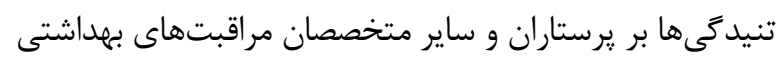
دارد، عبارت است از اختلالات روانتنى، ضعف سلامت روان راني،

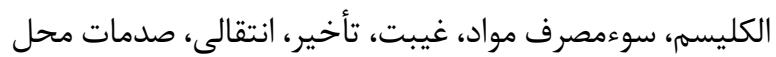
كار، اختلالات اسكلتى عضلانى، كاهش توانى توانايى ارائئ

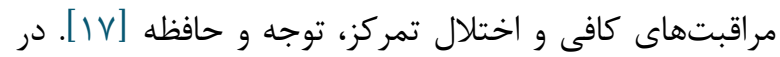

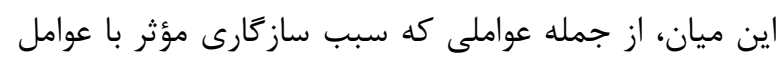

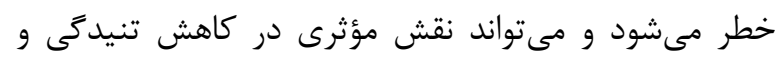

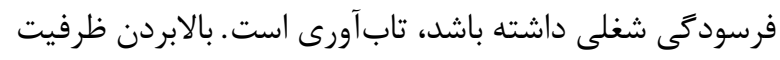

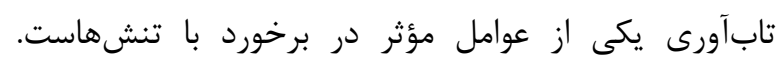

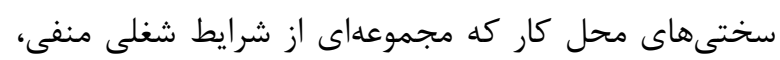

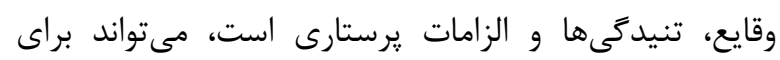

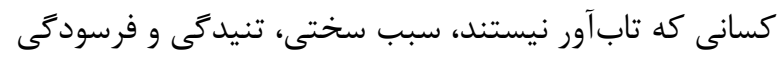

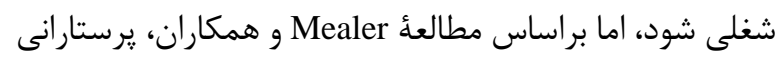

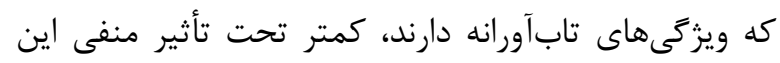
عوامل تنيدگىزا قرار مى گيرند [11]

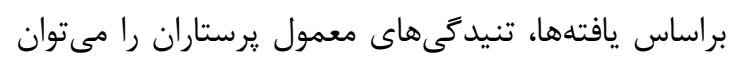

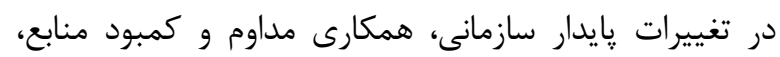

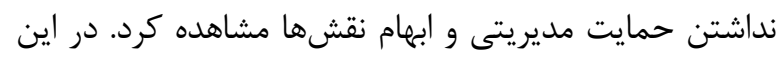

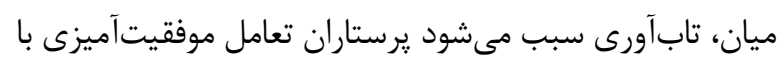

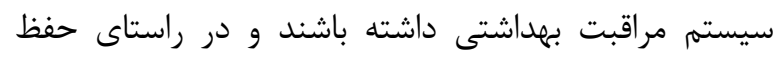
رضايت شغلى، بهزيستى و سلامتى خود و بيمار انشان توانا شوند راند

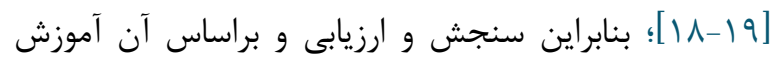

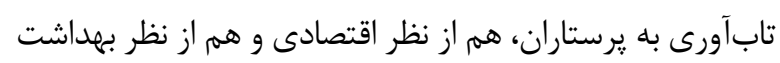

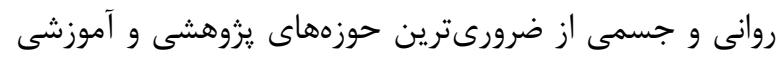
محسوب مىشود و اين امر مستلزم وجود ابزار مناسب برونى برونى
تغييرات ساز كارتر هستند. آنها بهدليل استفاده از منابع محافظتى

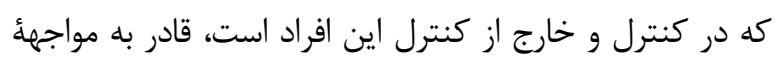

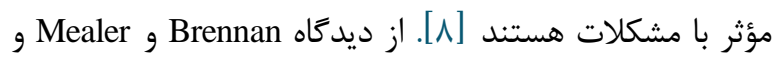
همكاران تابآورى، ارتباط با محيط اجتماعى، ارتباط با خاندان إنواده،

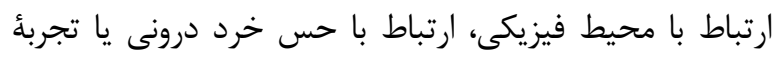

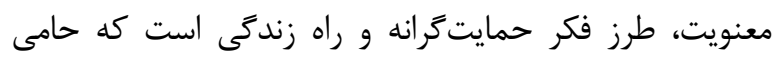

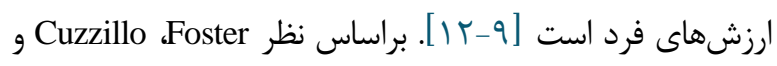

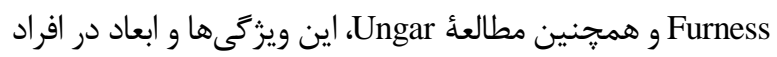

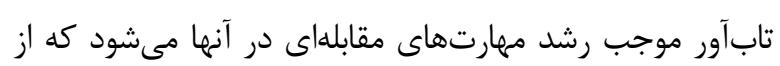

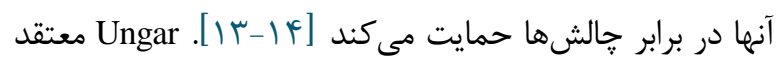

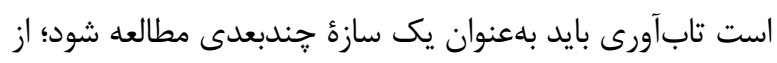

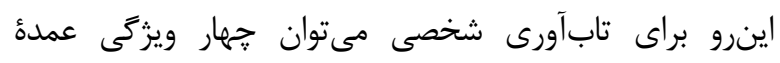

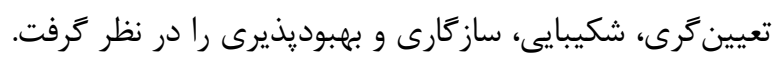

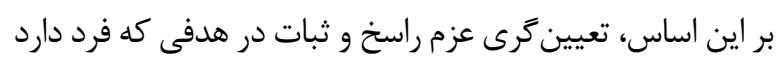

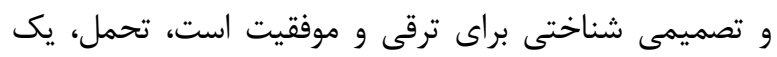

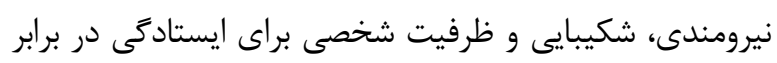

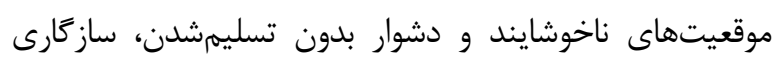

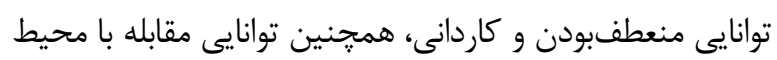

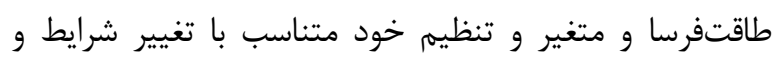

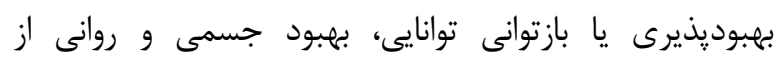

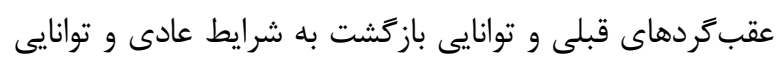

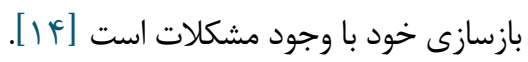
از طرف ديكر، شغل برستارى بهدليل ماهيت حرفهاى خود،

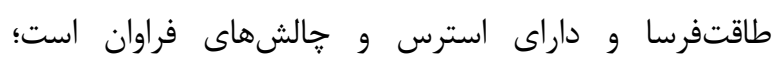
بلهورى كه بر كيفيت زندكى يرستاران تأثير مى كذارد؛ بنابراين

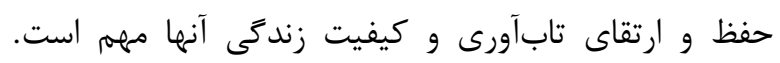

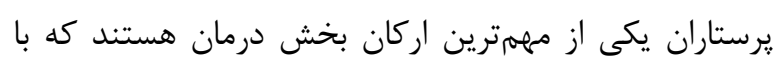

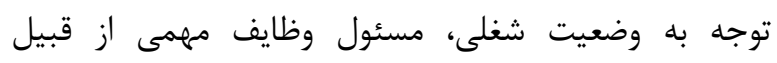

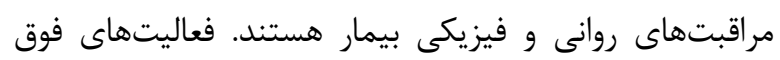

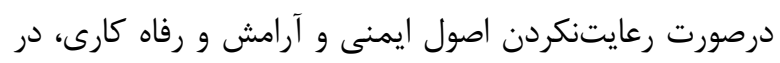
بروز اختلالات جسمانى و روانى اين قشر نقش بسز ايتى إيى دارد.

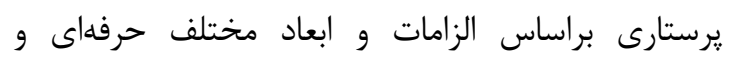

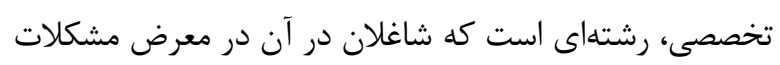

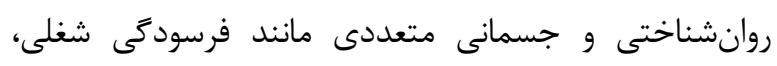

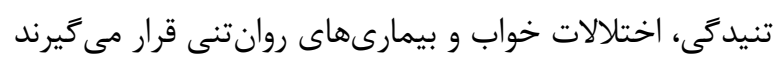

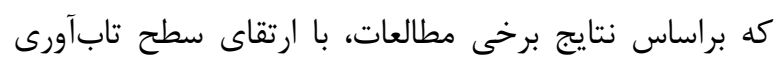

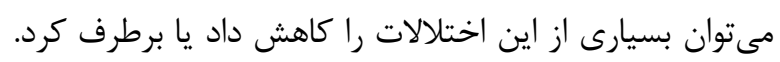

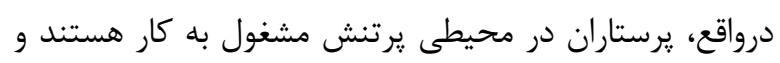


روش بر برسى

در اين يزوهش، • إ ا نفر از برستاران بيمارستانهاى شهر

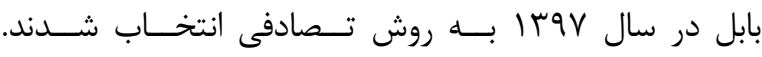
ترجمه و بررسى ويزَّى هاى روانسنجى مقياس "المقياس

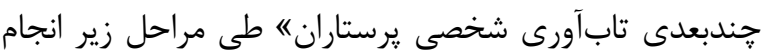

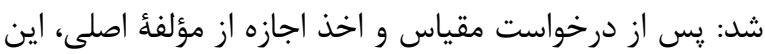
مقياس را دو نفر مسلط به هر دو زبان انتليسى و فارسى، از زبان اصلى به زبان فارسى ترجمه كردند. سيس دو ترجمه با هم مله مقايسه و با تغييرات مختصرى در لغات، نسخة نهايى تهيه شد.

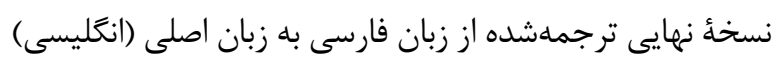

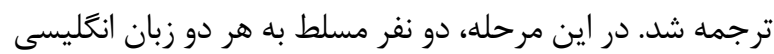
و فارسى كه با افراد اول در ارتباط نبودند، نسخة نهايى رائ را بار

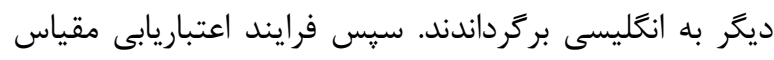

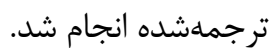
براى تعيين روايى محتوا بهصورت كمى و كيفى، مقياس

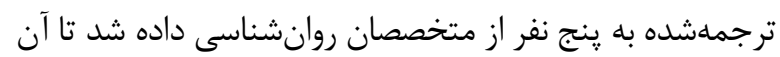

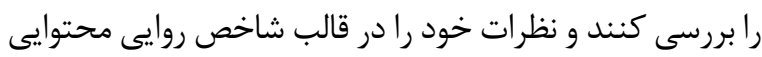

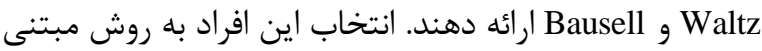
بر هدف انجام شد. تعيين روايى محتوايى كمى و كيفى در يك

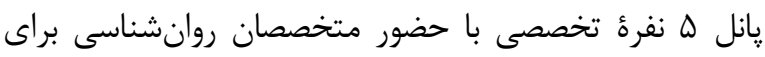

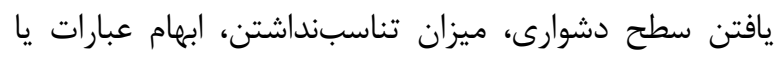
وجود نارسايى در معانى كلمات انجام و نظرات آنان بهصورت

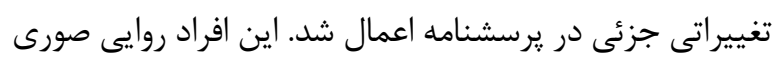

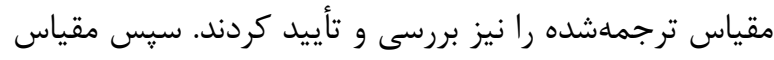
1. براى بررسى روايى صورى بلهورت كمى و كيفى در اختيار

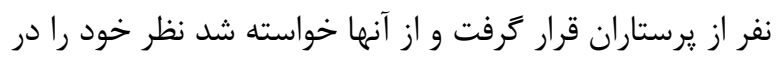

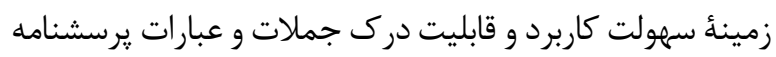
بيان كنند. در קايان اين مرحله، تغييرى در تعداد و محتواى براي

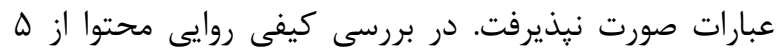

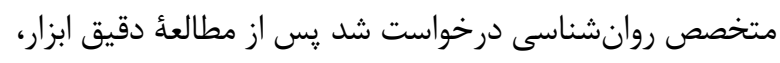
ديدَاههاى اصلاحى خود را بلصورت كتبى ارائه كنند. همجنين

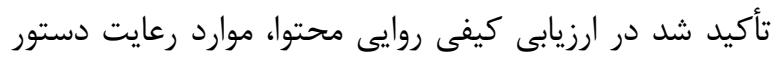

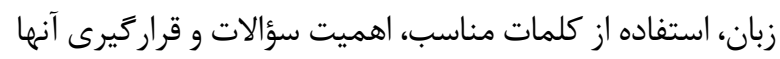
در جاى مناسب خود، زمان تكميل ابزار طراحىشده راست را مدنظر قرار دهند. يس از جمعآورى نظرات متخصصان، تغييرات بسيار

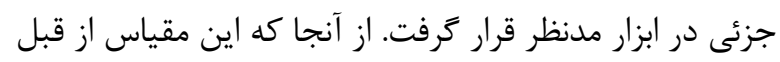

سنجش همهجانبئ تابآورى است. با توجه به اين ضرورت، تاكنون در ايران ابزارى كه براى سنجش تابآورى يرستاران آندان

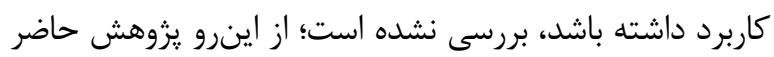

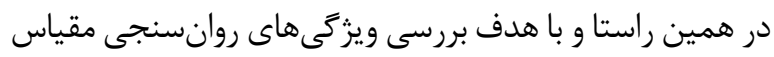
جندبعدى تابآورى شخصى يرستاران انجام شده است.

\section{مقياس جندبعدى تاب آورى شخصى يرستاران}

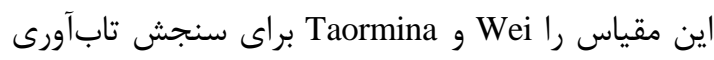
شخصى برستاران در محيط كار تدوين كردند. در اين مقياس

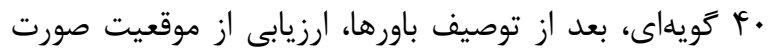

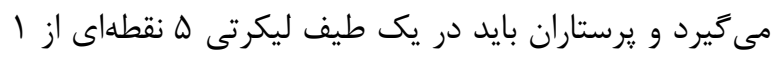

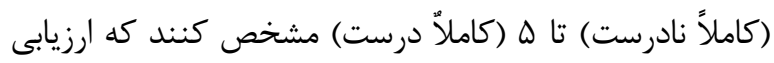

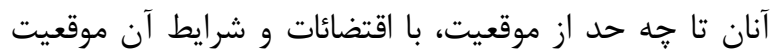
مشابه است. براى تفسير، واسخ مورد نظر فرد (در طيف ليكرتى

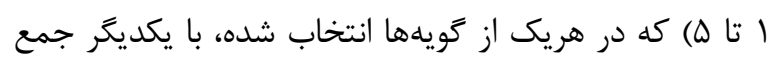

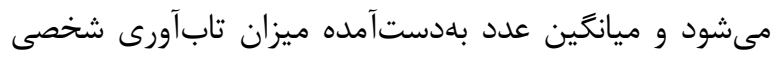
يرستاران در محيط كارى را نشان مى دهد؛ بلهطورى كه نمرة

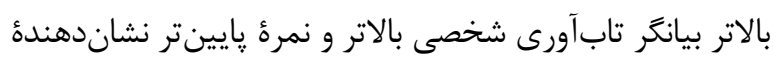

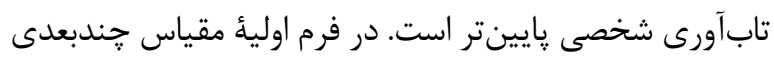

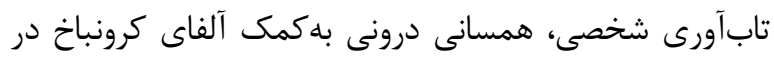

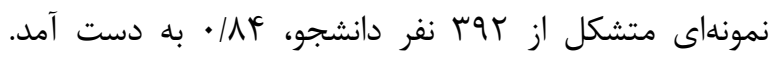

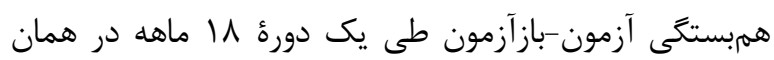

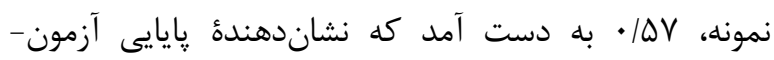

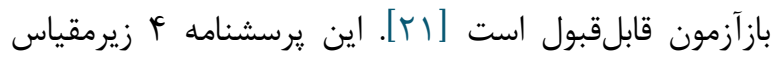

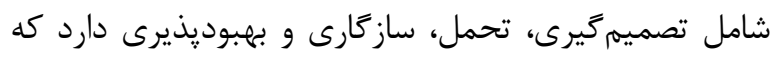

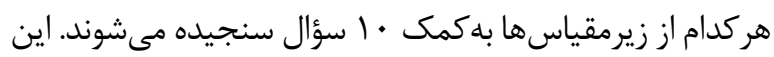

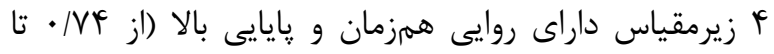

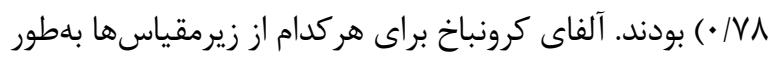

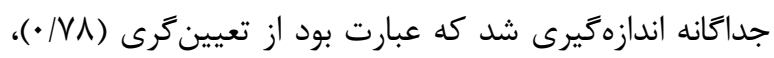

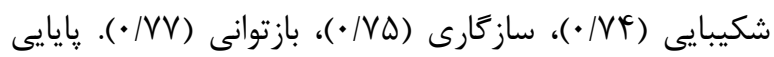

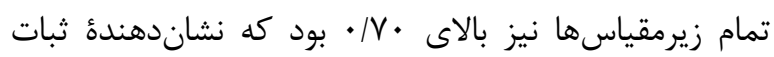

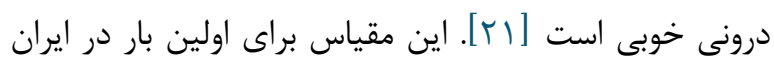

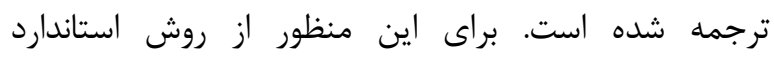
backward-forward translation بينفرهنكى مقياس هاى مرتبط با سلامت استفاده شد. در اين

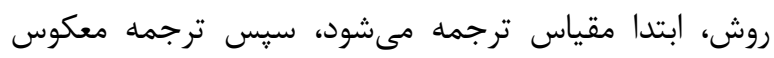

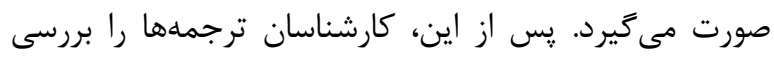
مى كنند و سيس مطالعهُ مقدمانى انجام مىشود. اين مطالعه نيز براساس اين راهبرد انجام شده است. 


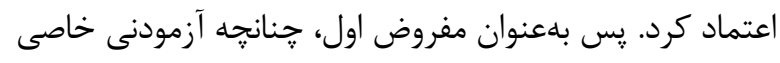

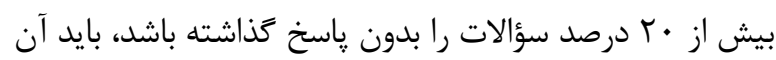
آزمودنى كنار كذاشته شود. دومين مفروض تحليل عاملى، اطمينانيافتن از اين موضوع

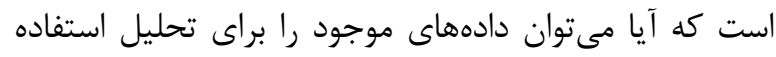

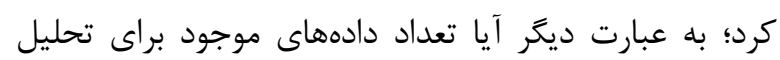

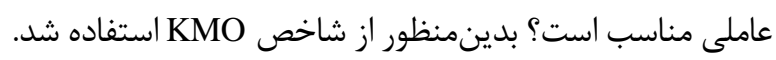

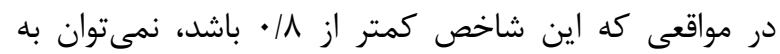

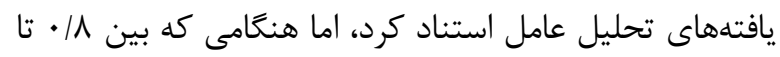

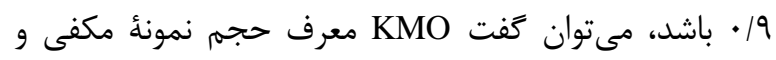

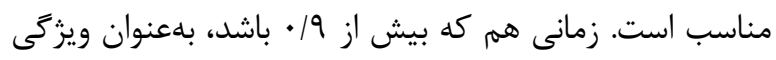

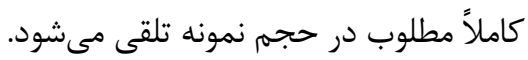

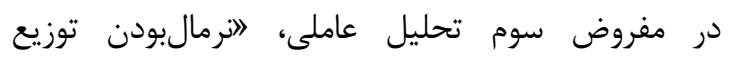

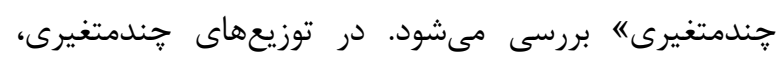

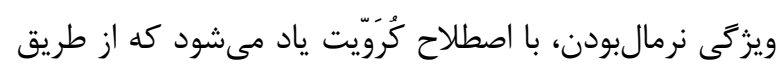

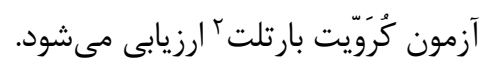

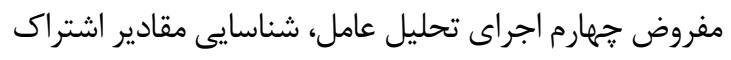

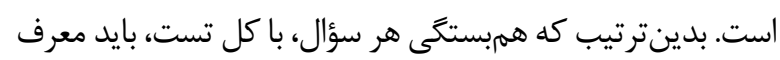

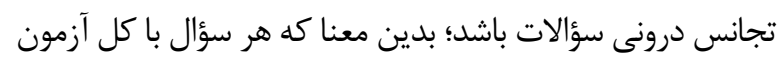

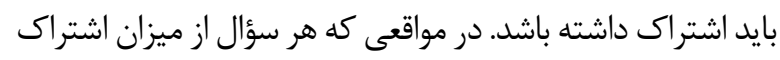

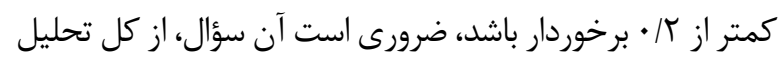

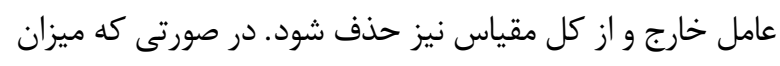

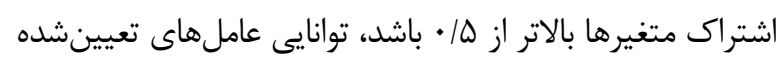
در تحليل عاملى را نشان مى دهد.

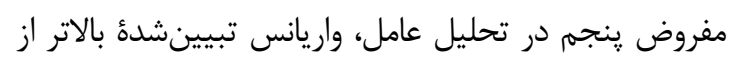

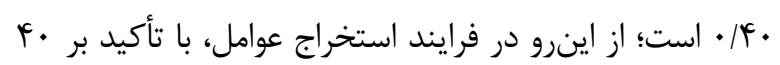

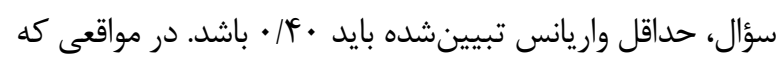

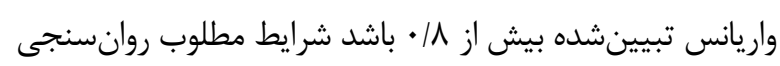

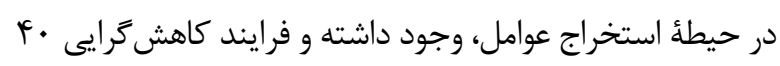

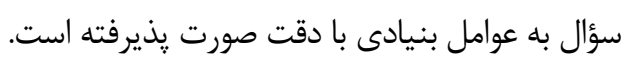

يافته ها

نتايج تحليل دادهها نشان مىدهد از • با يرستار مورد

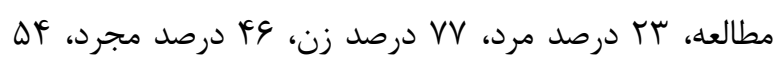

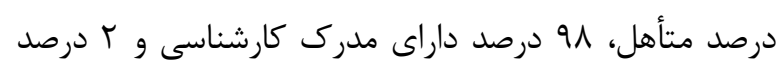

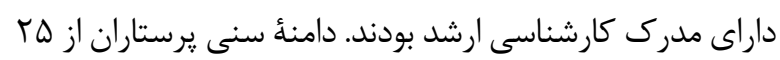

تدوين و ويزگكىهاى روانسنجى مناسب نمايان شده بود، به

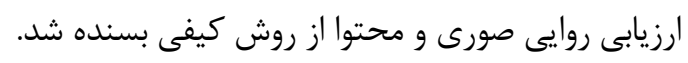

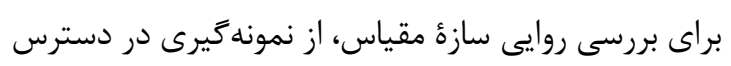

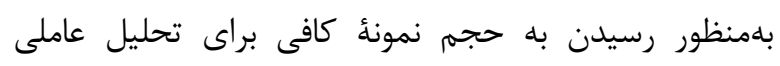
اكتشافى استفاده شد. تعداد نمونهُ مورد نياز براى تحلئ كافيل براي تحليل عاملى عاملى

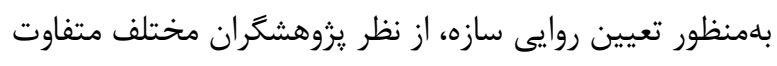

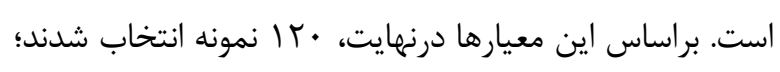

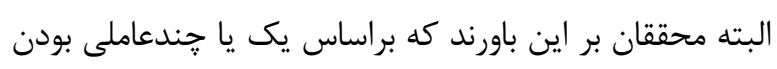

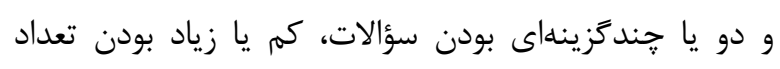

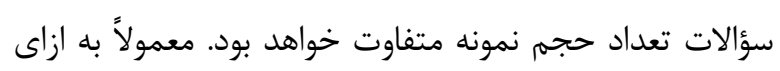

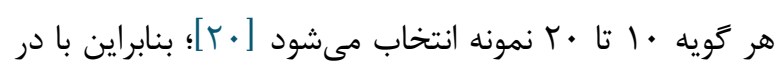

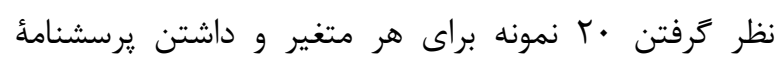

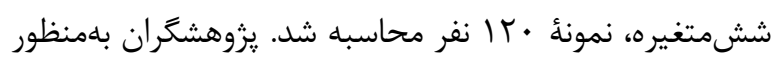

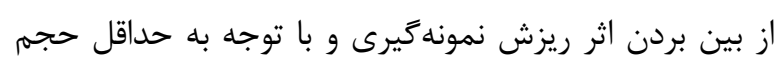

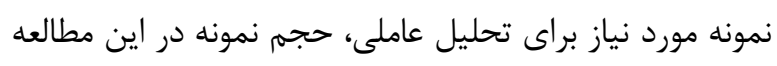

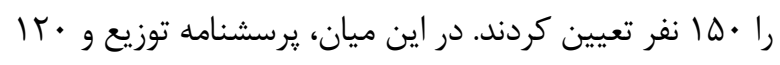

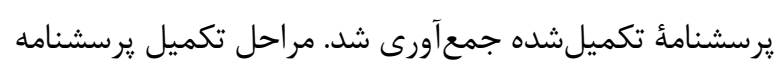

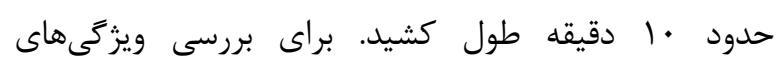

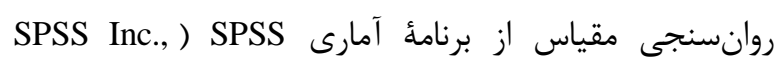
(Chicago, Ill., USA ملاحظات اخلاقى، هدف يُزوهش براى شركت كنيند آنان تشريح

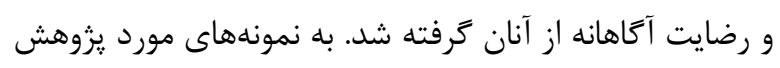
اطمينان داده شد كه اطلاعات دريافت شده از آنها، محرمانه

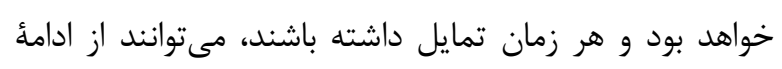

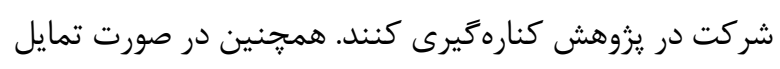

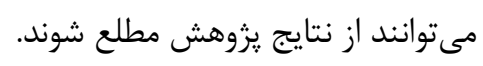

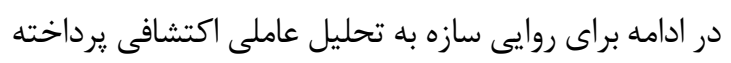

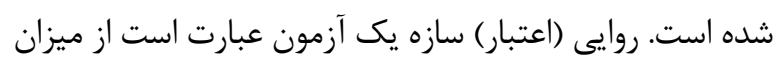

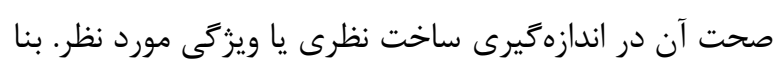
به تعريف، يك آزمون در صورتى داراى اعتبار سازه است كه آنه

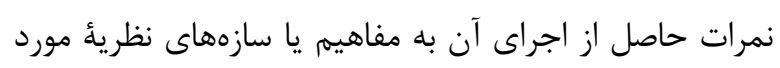
نظر، مربوط باشد. از آنجا كه دادههاى ازدسترفته يا تكميلنشده، فرايند

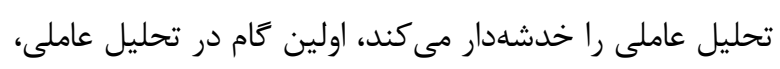

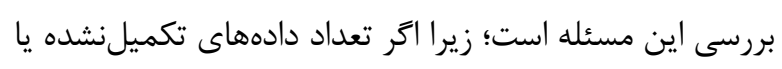

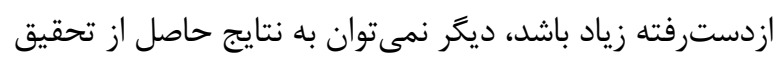

\section{${ }^{2}$. Bartlett's test of sphericity}


در بررسى دومين مفروض تحليل عاملى، براى ماتريس

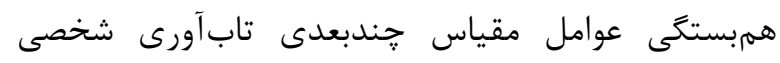

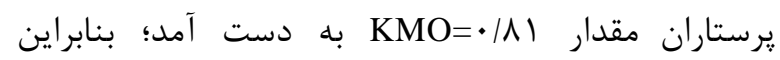

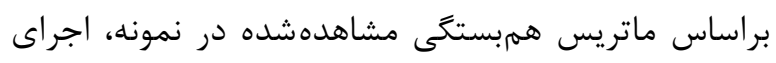
تحليل عاملى قابل توجيه است.

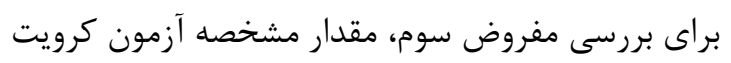

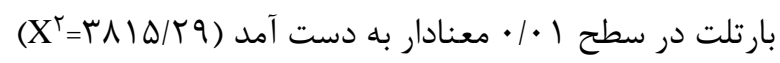

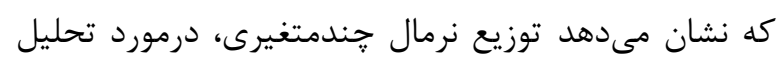

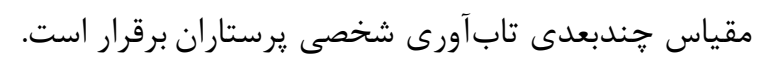

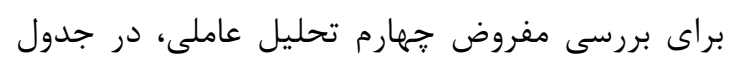

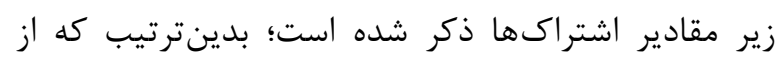

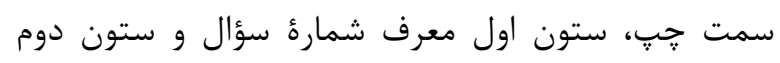

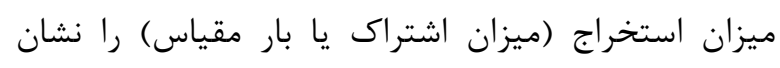

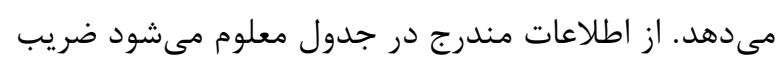

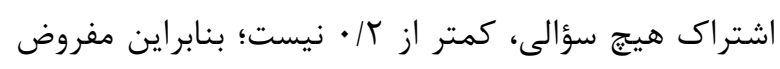

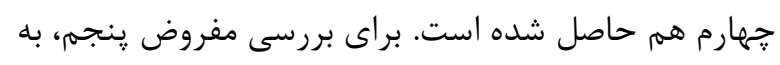

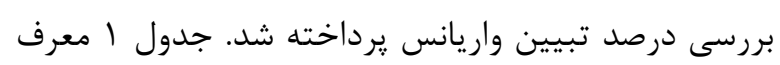

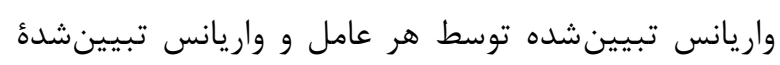

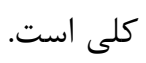

تا هال سال متغير بوده و ميانگين سنى آنها آس برآورد شده است.

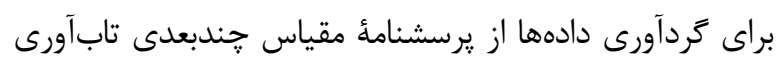

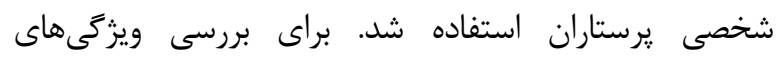

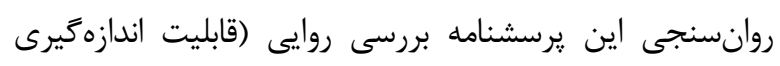

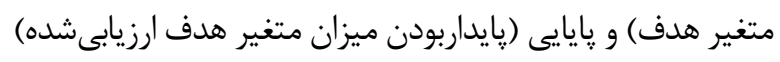
مدنظر قرار ترفت. در ادامه بلمنظور بررسى روايى سازء هممكرا از روش همسانى

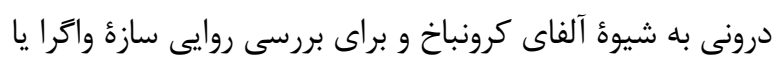

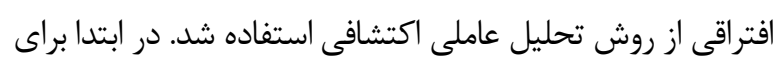

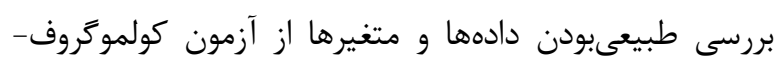

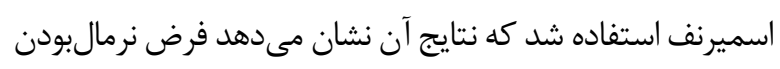
متغيرها برقرار است (ه •|•PC). براى بررسى اولين مفروض تحليل عاملى، از بررسى اوله اوليه

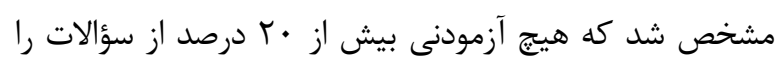

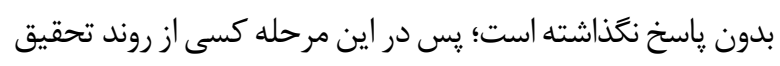

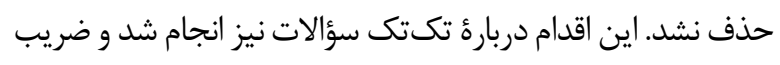

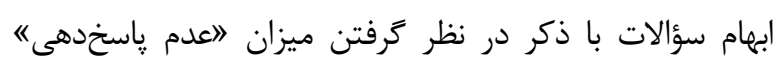

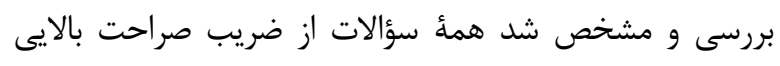

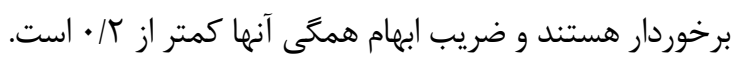

جدول ا. ارزش ويزه، درصد واريانس عاملها و درصد تراكمى واريانس تبيينشده در تحليل عاملى به روش مؤلفههاى اصلى

\begin{tabular}{|c|c|c|c|}
\hline درصد تراكمى واريانس تبيينشده & درصد واريانس تبيينشده & ارزش ويثه & 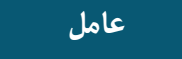 \\
\hline rt/lq & $r r / 19$ & $\mathrm{IT/N}$ & عامل تعيينگرى \\
\hline fi/tr & 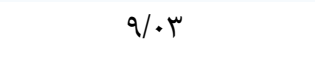 & W/ & عامل شكيبايى \\
\hline$F q / r \Delta$ & 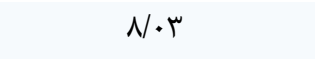 & 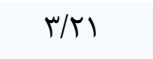 & عامل ساز گارى \\
\hline$\Delta \Delta / Y)$ & $\Delta / ৭ q$ & م/א & عامل بازتوانى \\
\hline
\end{tabular}

تراكمى است. عامل تعيين

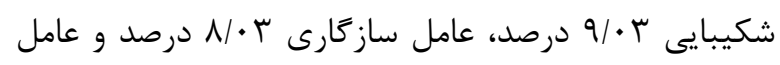

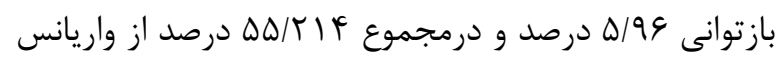

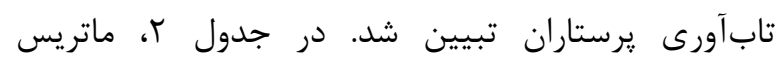

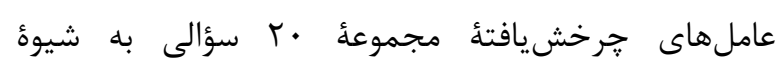
واريماكس آمده است.
جدول إ معرف واريانس تبيينشده است كه با استناد به بارهاى عاملى مجذورشده مرتبط با استخر اج عوامل بيان شده

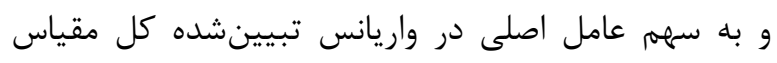
معطوف است. اولين ستون از سمت راست بئن بيانكر تعداد

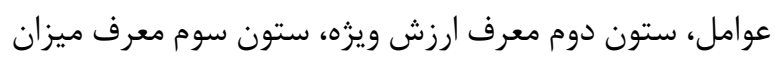

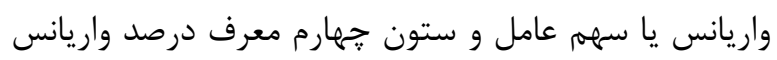




\begin{tabular}{|c|c|c|c|c|c|c|c|c|c|c|}
\hline 1. & 9 & $\wedge$ & $v$ & 9 & $\Delta$ & f & $r$ & $r$ & 1 & سؤالات \\
\hline.$/ 49$ & $\cdot / 9$ & $\cdot 109$ & $\cdot / 44$ & . AT & $\cdot \mid \Delta F^{F}$ & $\cdot / 4 q$ & $\cdot / 4$. & $\cdot|\Delta|$ & $\cdot / \& V$ & تعيين كامل 1. \\
\hline$r$. & 19 & 11 & IV & 19 & 10 & if & ir & ir & 11 & سؤالات \\
\hline . & $\cdot / \pi \Lambda$ & 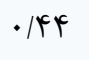 & .101 & $\cdot / 4 q$ & $\cdot / Q T$ & $\cdot|q|$ & $\cdot / 4 \wedge$ & . Mt & $\cdot / \pi \Lambda$ & عامل r. شكيبايى \\
\hline$r$. & $r q$ & $r \wedge$ & $r V$ & rq & $r \Delta$ & rF & rr & $r r$ & $r$ & سؤالات \\
\hline . MT & ع צא/. & (ז & .199 & $\cdot 190$ & $\cdot / \Delta V$ & $\cdot / \mu \Lambda$ & $\cdot / 4$. & . & r & عامل Гّ. ساز كارى \\
\hline r. & rq & rı & $r v$ & rq & rd & $r q$ & rr & rT & $r_{1}$ & سؤالات \\
\hline$\cdot / \& V$ & $\cdot / G T$ & $\cdot r \Lambda$ & .194 & سא/. & $\cdot / 4 q$ & $\cdot / F F$ & . & . & $\cdot / \& V$ & عامل f. بازتوانى \\
\hline
\end{tabular}

عبارت داراى بار عاملى بيشتر از ب/ • است و ميزان واريانس

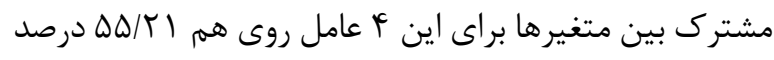

$$
\text { كل واريانس است. }
$$

ضريب آلفاى كرونباخ براى سنجش ميزان تكبعدىبودن

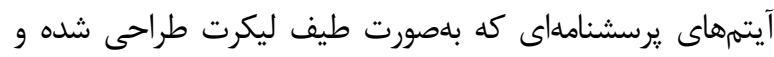

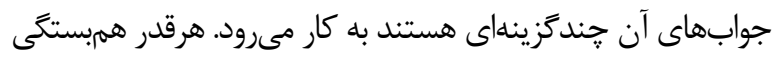

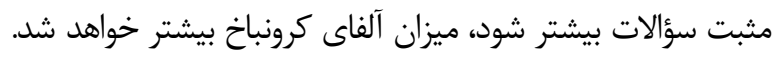

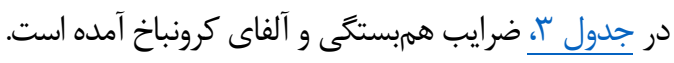

براساس جدول بـ، قدرت رابطه ميان عامل (متغير ينهان)

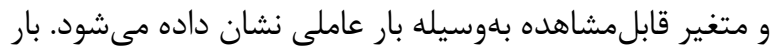

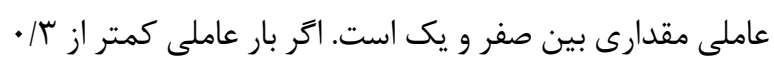

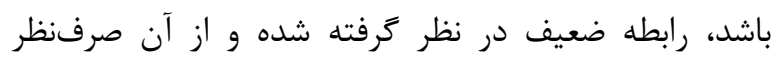

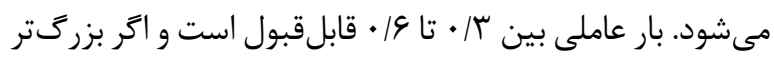

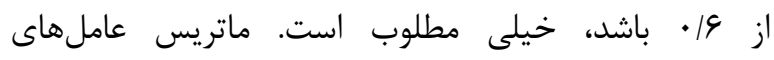

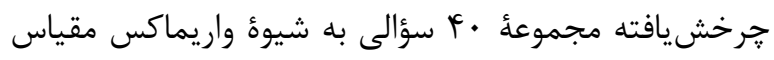

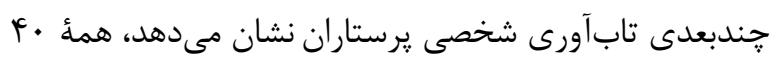

\section{جدول r. ضرايب همبستكى و آلفاى كرونباخ}

\section{آلفا}

\section{نمرة كل ناب آورى كرون}

$\begin{array}{ll}\cdot / V T & \cdot / 491 \\ \cdot / 14 & \cdot / 941 \\ \cdot / 81 & \cdot / 011 \\ \cdot / V \cdot & \cdot / 0 \cdot 1 \\ \cdot / 19 & \cdot / 941\end{array}$

به عامل سازگارى (Adaptability) با ضريب آلفاى كرونباخ

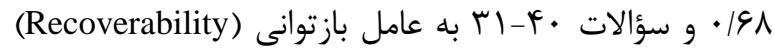

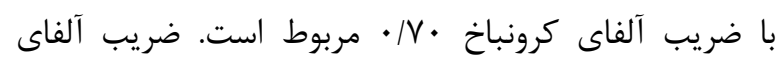

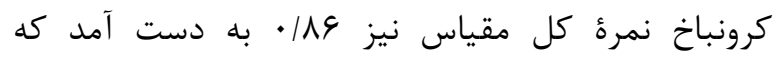

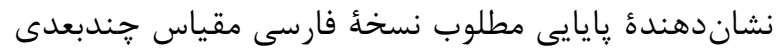

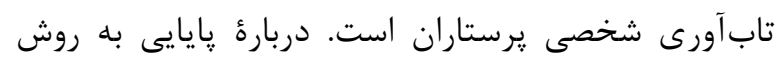

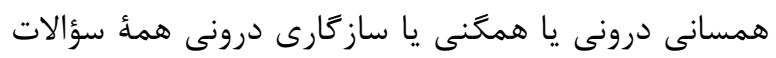

عامل تعيين (سؤرى (1الات • (1)

عامل شكيبايى (سؤالات • ·-11)

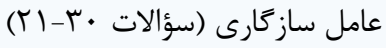

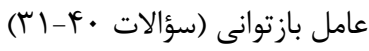

نمرءٔ كل تابآورى (كل سؤالات)
براى بررسى پايايى مقياس و عوامل استخراجشده آن از روش ضريب آلفاى كرونباخ استفاده شد. در تحليل دادههاى ياى

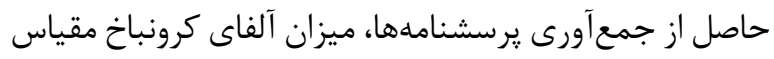

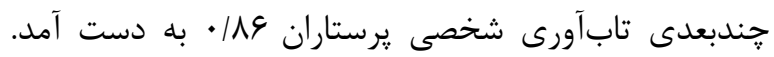

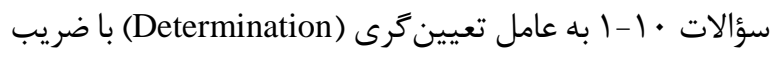

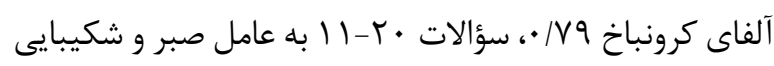
با ضريب آلفاى كرونباخ (Andurance) 
رضا سلطانىشال و همكاران 9

متوسط ارزيابى مىشود؛ بنابراين مقياس קندبعدى

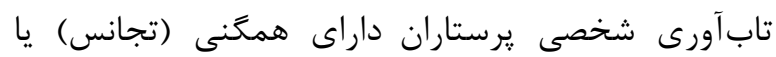

$$
\text { همسانى درونى متوسطى است. }
$$

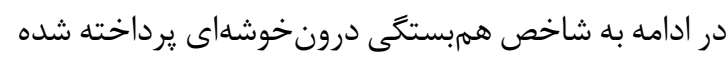

است. مقبولترين آزمون براى تعيين ثبات و ورايايى، آزمون

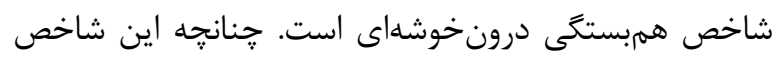

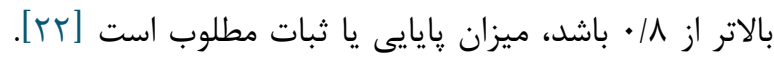

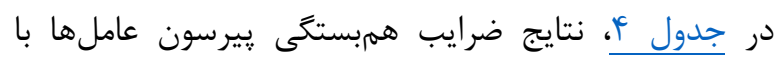
يكديخر و كل مقياس آمده است.
و مؤلفههاى مقياس، مىتوان مشاهده كرد طيف آلفاى

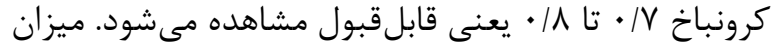

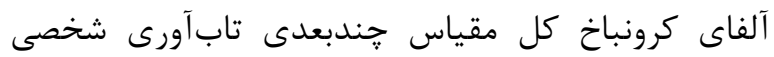

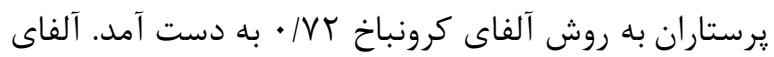

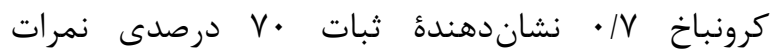

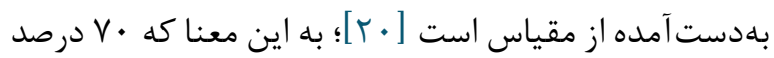

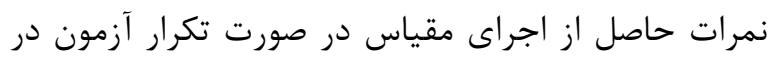

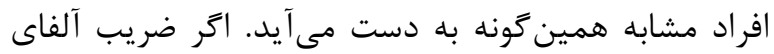

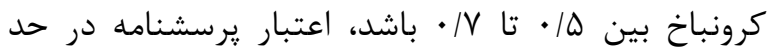

جدول F. نتايج ضرايب همبستكى بيرسون عاملها با يكديگر و كل مقياس

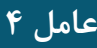

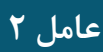

$\begin{array}{ccc} & 1 & \cdot / V T \\ 1 & \cdot / 14 & \cdot / 99 \\ .19 \mathrm{~V} & \cdot / 0 \Lambda & \cdot / \mathrm{VT}\end{array}$

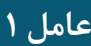

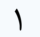

$\cdot \mid \Delta T$

$\cdot 19 \wedge$

$\cdot / \mathrm{VT}$

.199

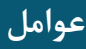

$$
\text { شازين }
$$

ويزه بالاتر از رقم ا، معرف عامل بنيادى است، اما در آزمونهاى

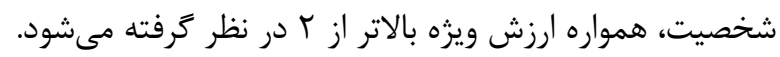

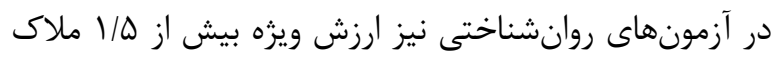

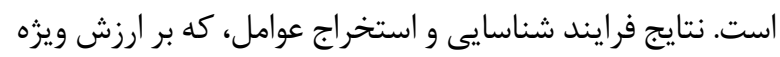
بيش از ه/ أأكيد شده، در شكل إينا بيان شده است.
با توجه به جدول عا، ضرايب همبستخى همأ عاملهاى

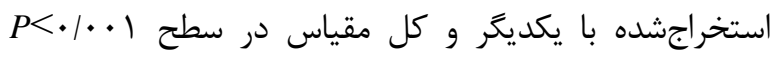

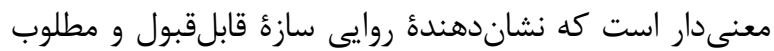
نسخهُ فارسى مقياس جندبعدى تابآورى شخصى است. شكل

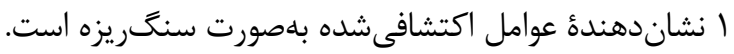

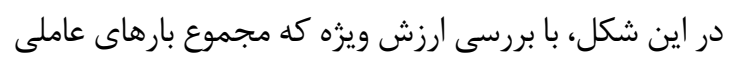
مجذور شده است، بايد به شناسايى عوامل اصلى برداخت. ارزش رنش

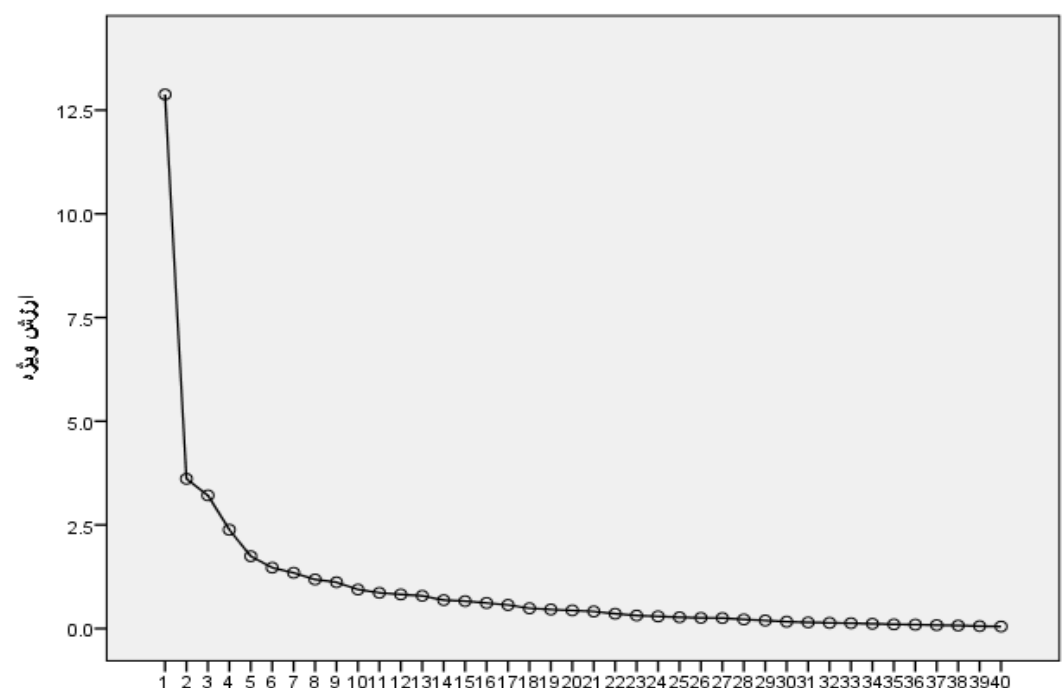

مولكه

شكل ا. نمودار سنََريزهُ مقياس خندبعدى تاب آورى شخصى يرستاران 
•ا ويزَكىهاى روانسنجى مقياس خندبعدى تاب آورى شخصى برستاران

\section{بحث}

تنيدگىزا و دشوار بدون تسليمشدن مفهومسازى شده است.

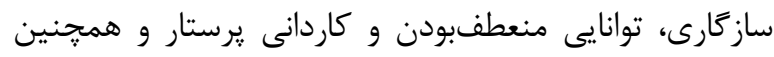

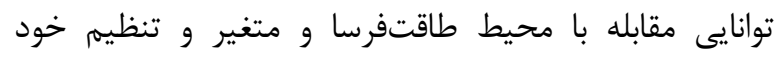

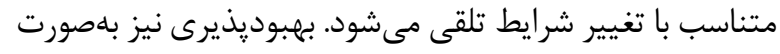

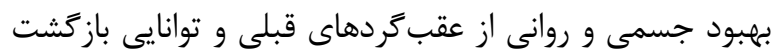

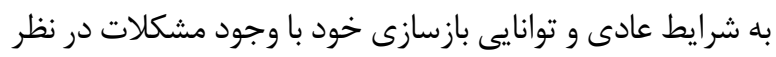

$$
\text { كَرفته مىشود. }
$$

بمنظور اعتبار سازه، تحليل عاملى اكتشافى صورت كرفت.

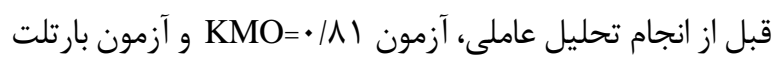
براى كرويت برابر

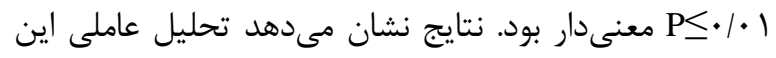

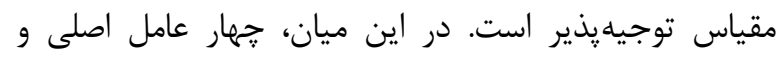

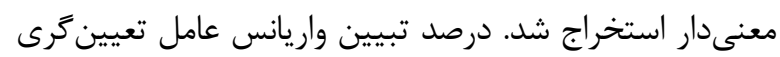

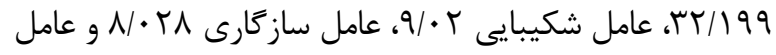

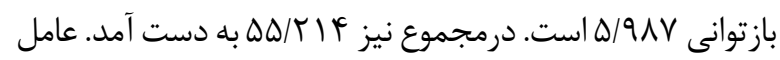

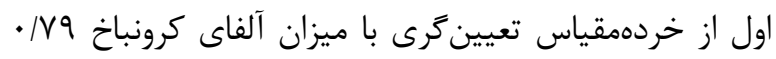

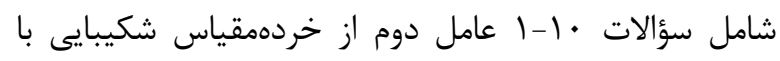

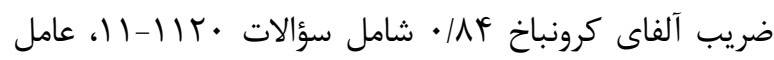

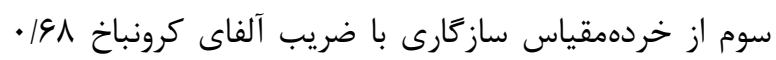

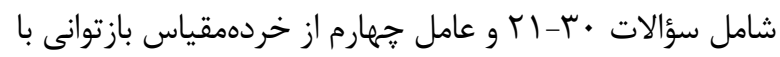

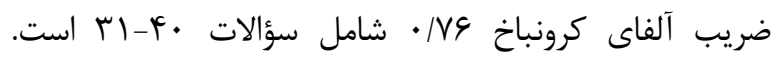

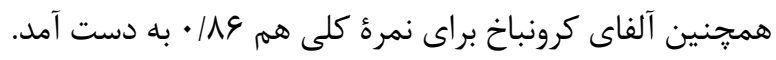

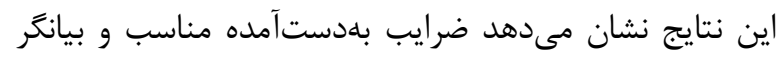
همسانى درونى كل مقياس و خردهمقياسهاى آن است. نتايج

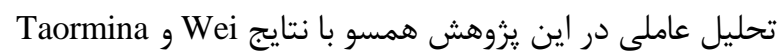

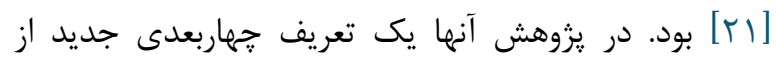

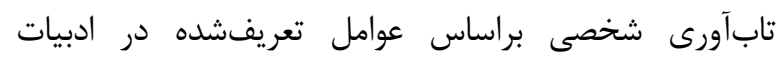

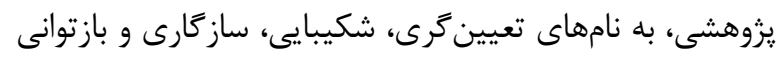

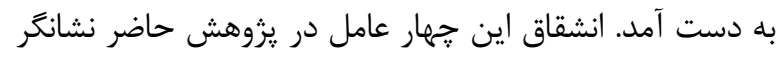

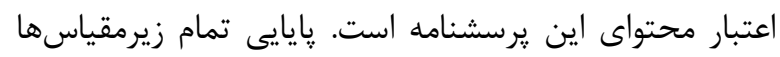

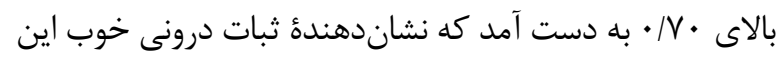

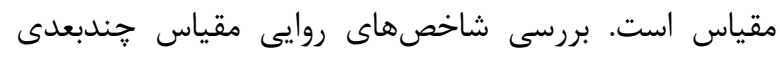

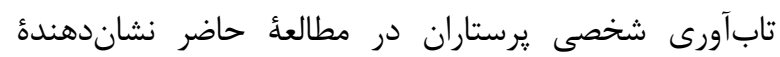

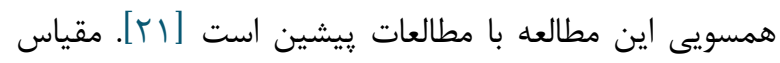

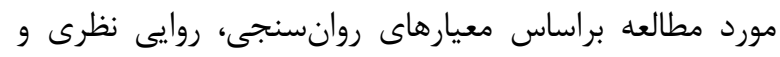

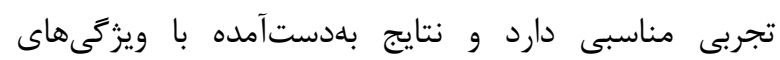

يكى از موضوعات مهم متخصصان در مطالعات حوزه

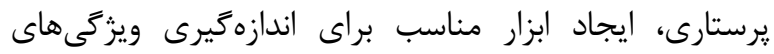

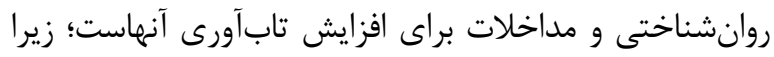
يرستاران بهدليل استرسهاى ناشى از مراقبتهاى تخصصى و

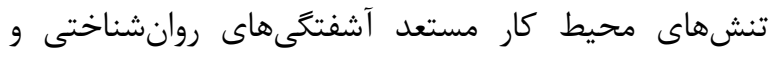

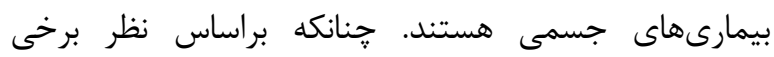

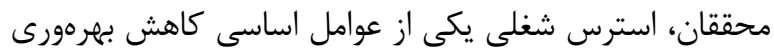

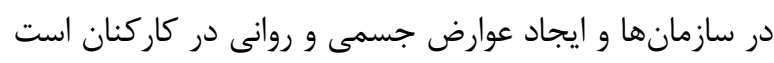

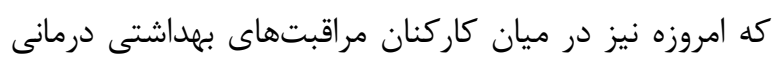

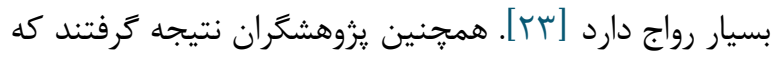
يرستارى يكى از يراسترسترين مشاغل است؛ به نحوى كه تنش

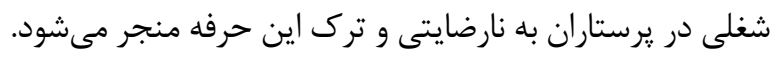

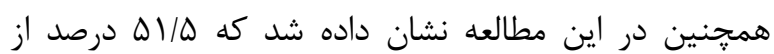

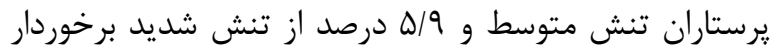

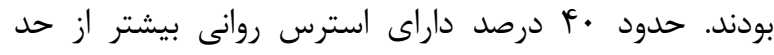

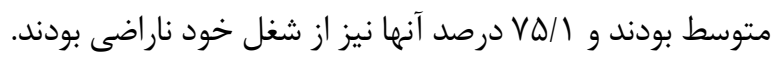

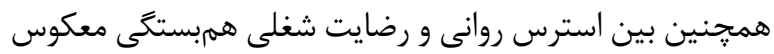

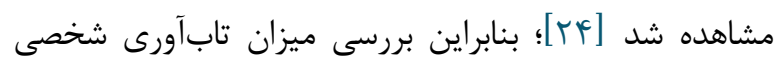

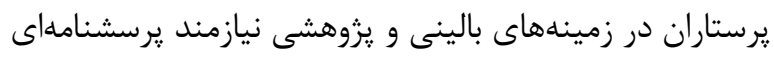

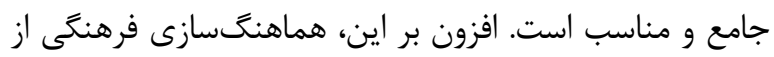

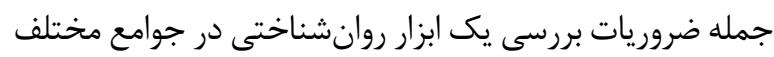

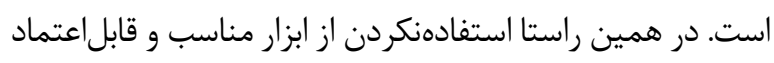

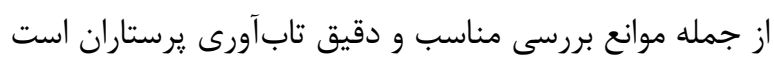

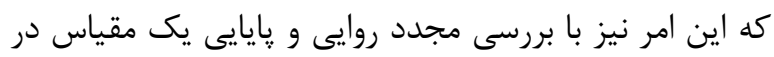

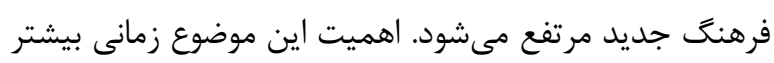

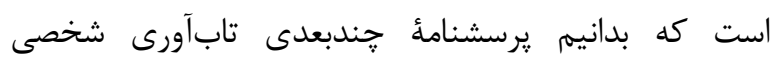
يرستاران تنها يرسشنامهاى است كه ابعاد مختلف تاب آورى در

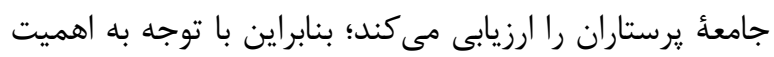

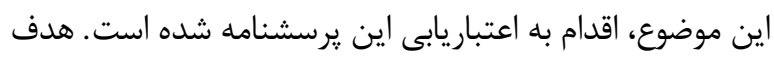

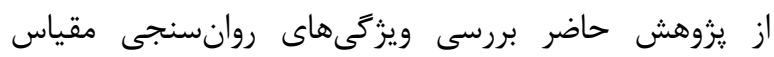

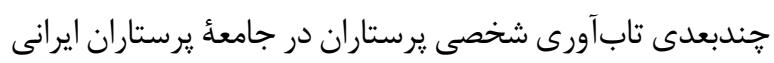

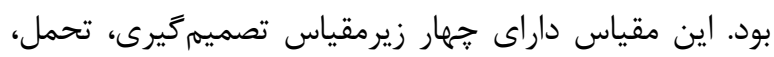

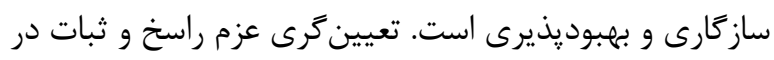

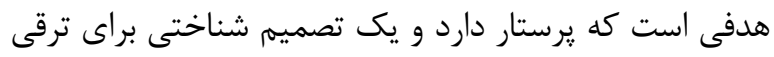

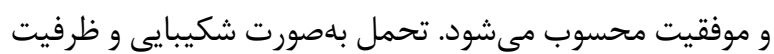

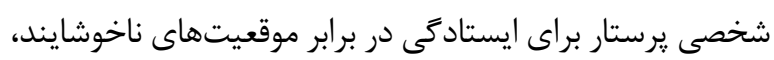


تجربئ احساسات مثبت در ميان وقايع و فعاليتهاى استرسآور

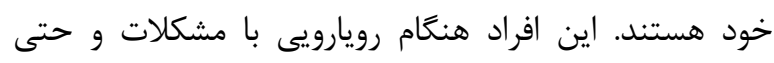

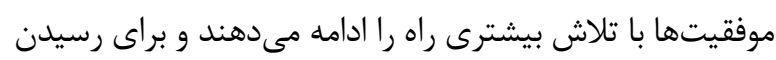

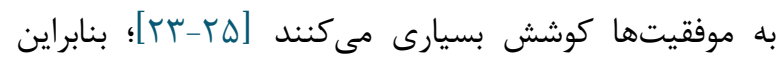

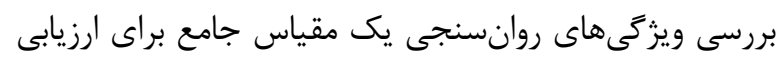

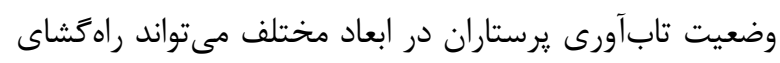

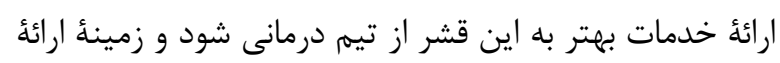

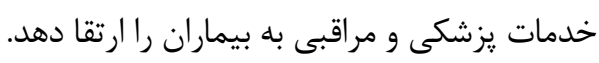

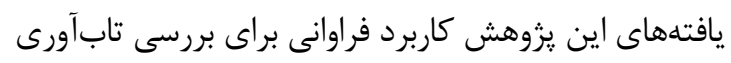

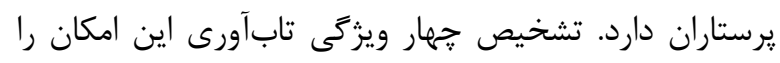

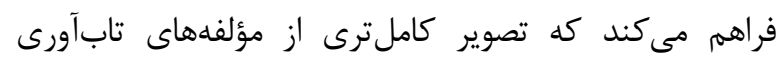

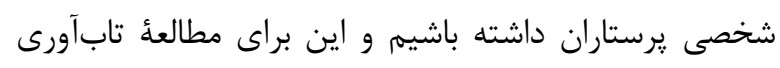

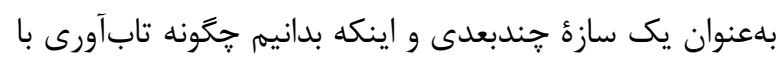

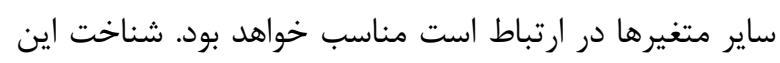

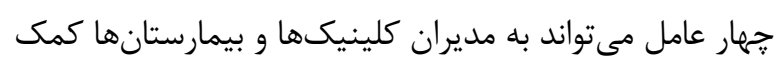

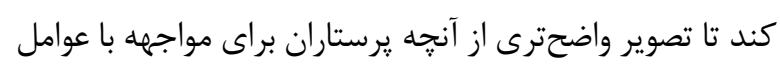

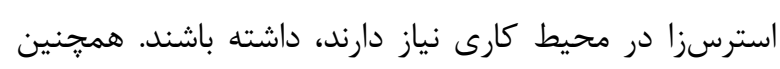

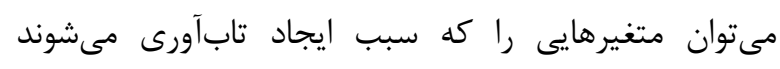

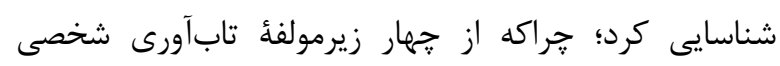

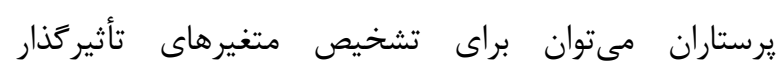

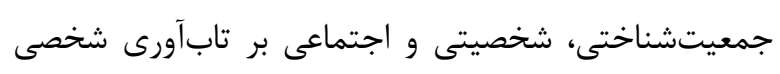

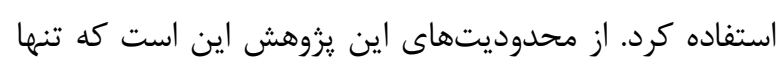

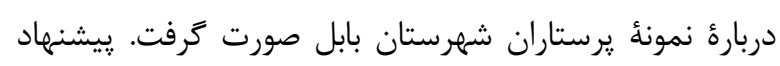

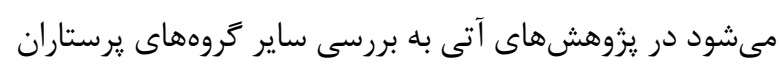

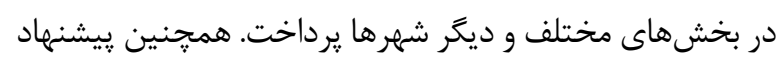

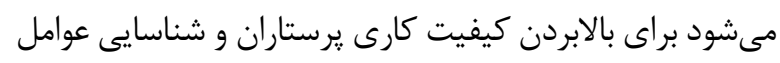

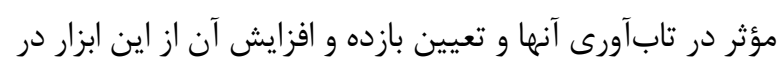
يزوهشها و مراكز درمانى استفاده شود.

\section{نتيجه كيرى}

روايى و ثبات درونى يرسشنامةٔ تاب آورى شخصى يرستاران

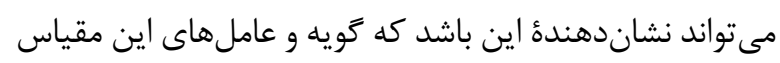

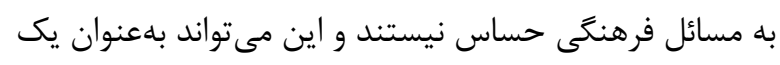

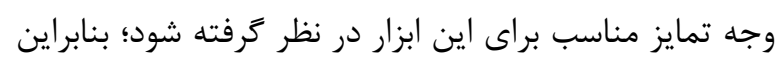

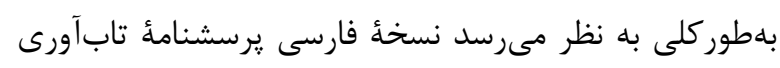

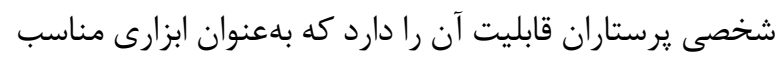

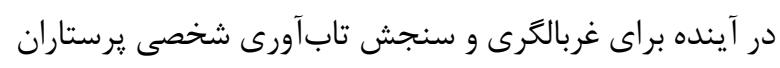

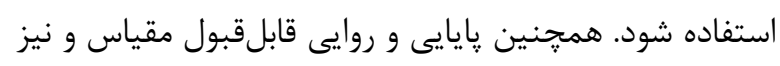

روانسنجى اغلب يزوهشهاى زَزارششده در اين زمينه

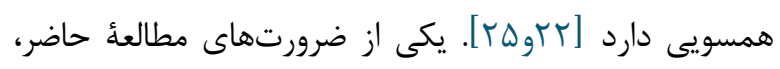

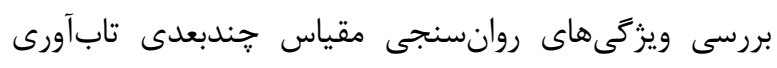

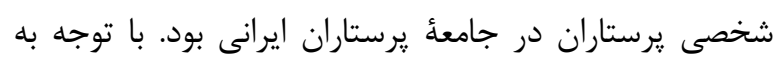

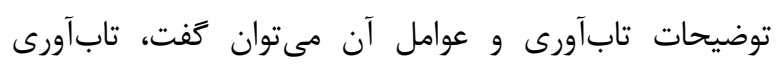
شخصى منبعى براى محافظت از افراد در برابر مشكلات و و اثرات

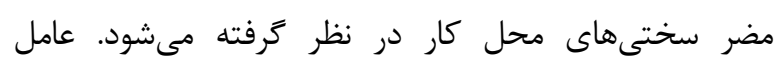
تعيين

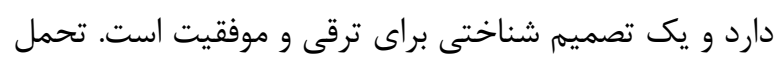

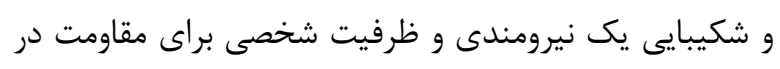

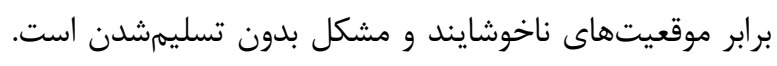

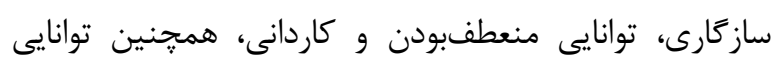

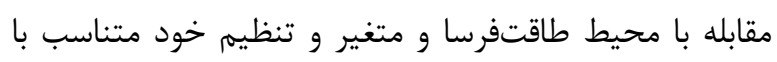
تغيير شرايط است. بهبوديذيرى توانايى بهبود جسمى و وروانى از

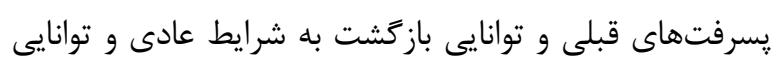

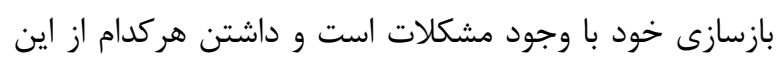

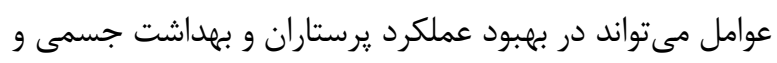
روانى آنها نقش مؤثرى داشته باشد.

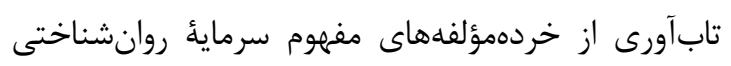

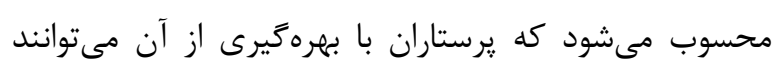

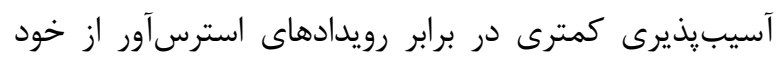

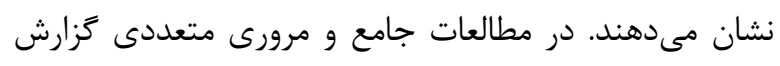

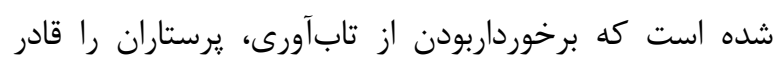

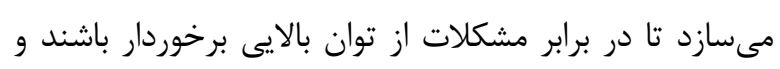

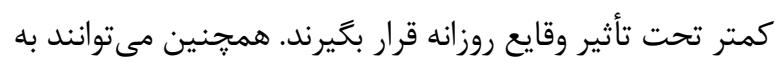

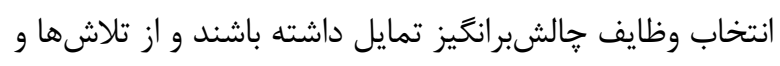

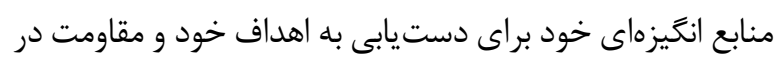

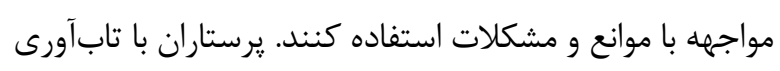

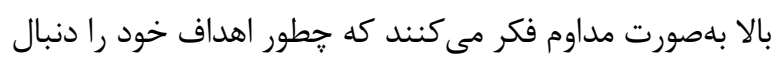

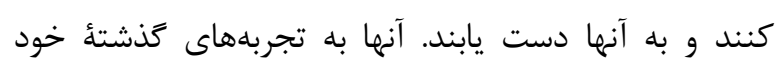

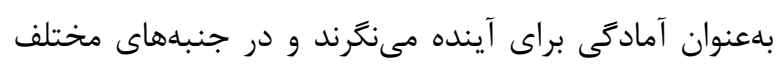

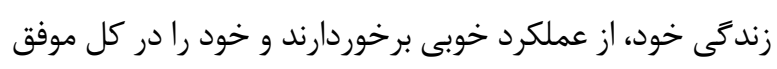

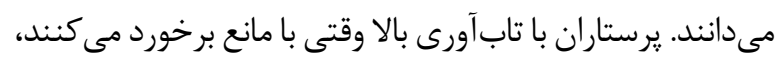

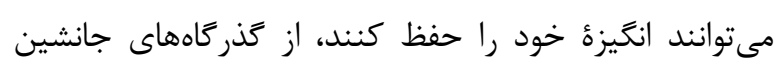

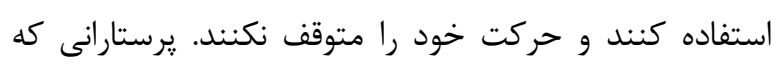

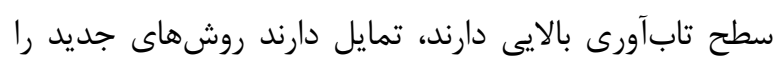

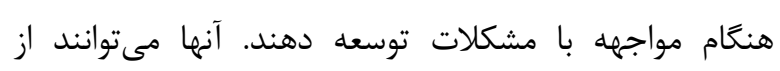
تجربههاى احساسى منفى سريعتر عبور كنند و بيشتر مستعد 


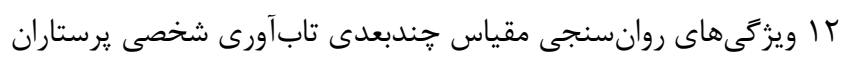

$$
\text { تعارض در منافع منابع مالى منابع مالى اين مطالعه توسط نويسند }
$$

\section{References}

1. Bahrami M. Nurses' quality of life in medical-surgical wards of an oncology center affiliated to the Isfahan University of Medical Sciences. Nursing Journal of the vulnerable. 2016;3(7):36-46.

2. Ansari H, Abbasi M. Health-related quality of life among nurses in Zahedan University of Medical Sciences Hospitals. J Hosp. 2015;14(3):47-55.

3. Mohammadi M, Mozaffari N, Dadkhah B, Etebari Asl F, Etebari Asl Z. Study of work-related quality of life of nurses in Ardabil Province Hospitals. J Healthc Manag. 2017;19(3):108-6.

4. Aghakhani N, Pouriran M, Ataei L, Aliafsari E, Soheili A. Correlation between night shift and lowback pain in nurses who work in educational hospitals in Tabriz, Iran. Urmia Nurs. Midwifery Fac. 2014;12(7):515-21.

5. Stevanin S, Palese A, Bressan V, VehviläinenJulkunen K, Kvist T. Workplace-related generational characteristics of nurses: A mixed-method systematic review. J Adv Nurs. 2018;74(6):1245-63. [DOI:10.1111/jan.13538] [PMID]

6. Cruz JP. Quality of life and its influence on clinical competence among nurses: a self-reported study. J Clin Nurs. $2017 \quad$ Feb;26(3-4):388-99. [DOI:10.1111/jocn.13402] [PMID]

7. Li Y, Cao F, Cao D, Liu J. Nursing students' posttraumatic growth, emotional intelligence and psychological resilience. Int $\mathbf{J}$ Ment Health Nurs. 2015;22(5):326-32. [DOI:10.1111/jpm.12192] [PMID]

8. Mealer M, Schmiege SJ, Meek P. The ConnorDavidson Resilience Scale in critical care nurses: a psychometric analysis. J Nurs Meas. 2016;24(1):2839. [DOI: 10.1891/1061-3749.24.1.28] [PMID] [PMCID]

9. Brennan EJ. Towards resilience and wellbeing in nurses. British J Nurs. 2017;12;26(1):43-7. [DOI:10.12968/bjon.2017.26.1.43] [PMID]

10. Delgado C, Upton D, Ranse K, Furness T, Foster K. Nurses' resilience and the emotional labour of nursing work: An integrative review of empirical literature. Int J Nurs Stud. 2017;70:71-88 [DOI:10.1016/j.ijnurstu.2017.02.008] [PMID]

$$
\begin{aligned}
& \text { كوتاهبودن و سهولت اجراى آن، زمينه را براى بهكارگيرى } \\
& \text { وسيعتر آن فراهم مى كند. } \\
& \text { سياسگز ارى } \\
& \text { از همة كسانى كه در اين تحقيق شركت كردند و ما را در } \\
& \text { انجام آن يارى رساندند، تشكر و قدردانى مى كنيم. اين تحقيق } \\
& \text { بدون حمايت مالى سازمان يا نهاد خاصى انجام گرفته است. }
\end{aligned}
$$

11. Mealer M, Hodapp R, Conrad D, Dimidjian S, Rothbaum BO, Moss M. Designing a resilience program for critical care nurses. AACN Adv Crit Care. 2017;28(4):359-65. [DOI:10.4037/aacnacc2017252] [PMID] [PMCID]

12. Mealer M, Jones J, Meek P. Factors affecting resilience and development of posttraumatic stress disorder in critical care nurses. Am J Crit Care. 2017 May;26(3):184-92. [DOI:10.4037/ajcc2017798] [PMID] [PMCID]

13. Foster K, Cuzzillo C, Furness T. Strengthening mental health nurses' resilience through a workplace resilience programme: A qualitative inquiry. Int $\mathrm{J}$ Ment Health Nurs. 2018;25(5-6):338-48. [DOI:10.1111/jpm.12467] [PMID]

14. Ungar M. Resilience across cultures. Br J Soc Work. 2008.;8(2):218-35. [DOI:10.1093/bjsw/bcl343]

15. Thomas LJ, Asselin M. Promoting resilience among nursing students in clinical education. Nurse Educ Pract. [DOI:10.1016/j.nepr.2017.10.001] [PMID] 2018;28:231-4.

16. Reyes AT, Andrusyszyn MA, Iwasiw C, Forchuk C, Babenko-Mould Y. Resilience in nursing education: An integrative review. J Nurs Edu. 2015;54(8):43844. [DOI:10.3928/01484834-20150717-03] [PMID]

17. Rushton $\mathrm{CH}$, Batcheller J, Schroeder K, Donohue P. Burnout and resilience among nurses practicing in high-intensity settings. Am J Crit Care 2015;24(5):412-20. [DOI:10.4037/ajcc2015291] [PMID]

18. Sanders ED. Nursing resilience: A nursing opportunity. Nurs Admin Q. 2015;39(2):132-6. [DOI:10.1097/NAQ.0000000000000091] [PMID]

19. Shimoinaba K, O'Connor M, Lee S, Kissane D. Nurses' resilience and nurturance of the self. Int $\mathrm{J}$ Palliat Nurs. 2015;21(10):504-10. [DOI:10.12968/ijpn.2015.21.10.504] [PMID]

20. Mokhlesi SS, Kariman N, Ebadi A, Khoshnejad FA, Dabiri F. Psychometric properties of the questionnaire for urinary incontinence diagnosis of married women of Qom city in 2015. J Rafsanjan Uni Med Sci. 2017;15(10):955-66. 
21. Wei W, Taormina RJ. A new multidimensional measure of personal resilience and its use: $\mathrm{C}$ hinese nurse resilience, organizational socialization and career success. Nurs Inq. 2014;21(4):346-57. [DOI:10.1111/nin.12067] [PMID]

22. Mohammadbeigi A, Mohammadsalehi N, Aligol M. Validity and reliability of the instruments and types of measurments in health applied researches. J Rafsanjan Uni Med Sci. 2015;13(12):1153-70.

23. Rayan A, Mo'men SISAN OB. Stress, workplace violence, and burnout in nurses working in King Abdullah Medical City during Al-Hajj season. J Nurs Re. 2019;27(3):e26. [DOI:10.1097/jnr.0000000000000291] [PMID] [PMCID]

24. Hazavehei MM, Moghimbeigi A, Hamidi Y. Assessing stress level and stress management among Hamadan hospital nurses based on precede model. Horiz Transl Med Sci. 2012;18(2):78-85.

25. Polit DF, Beck CT, Owen SV. Is the CVI an acceptable indicator of content validity? Appraisal and recommendations. Res Nurs Health. 2007;30(4):459-67. [DOI:10.1002/nur.20199] [PMID] 